\title{
Functional Interaction between Serotonin and Other Neuronal Systems: Focus on In Vivo Microdialysis Studies
}

\author{
Hideya Saito, Machiko Matsumoto, Hiroko Togashi and Mitsuhiro Yoshioka \\ First Department of Pharmacology, Hokkaido University School of Medicine, Sapporo 060, Japan
}

Received July 14, 1995

\begin{abstract}
In this review, the functional interactions between serotonin (5-HT) and other neuronal systems are discussed with the focus on microdialysis studies in the mammalian brain (mainly rats). 5-HT release is negatively regulated not only by somatodendritic $5-\mathrm{HT}_{1 \mathrm{~A}}$ and terminal $5-\mathrm{HT}_{1 \mathrm{~B}}\left(5-\mathrm{HT}_{\mathrm{ID}}\right)$ autoreceptors but also by $\alpha_{2}$-adrenergic and $\mu$-opioid heteroreceptors that are located on serotonergic nerve terminals. 5-HT by itself is involved in the inhibitory effects of noradrenaline release and the facilitatory regulation of dopamine release via multiple 5-HT receptors. Acetylcholine release appears to be regulated by inhibitory $5-\mathrm{HT}_{\mathrm{B}}$ heteroreceptors located on cholinergic nerve terminals. Long-term treatment with 5 HT-uptake inhibitors and noradrenaline-uptake inhibitor produces desensitization of 5-HT $1 \mathrm{~A}$ autoreceptors and $\alpha_{2}$-heteroreceptors, respectively, which may be related therapeutically to the delayed onset of the effects of antidepressants. Some microdialysis studies have predicted that the combination of a 5-HT-uptake inhibitor and $5-\mathrm{HT}_{1 \mathrm{~A}}$-autoreceptor antagonist might produce much greater availability of 5-HT in the synaptic cleft in terms of much faster induction of subsensitivity of $5-\mathrm{HT}_{1 \mathrm{~A}}$ autoreceptors. Clinical trials based on this hypothesis have revealed that combination therapy with a 5-HT-uptake inhibitor and 5 - $\mathrm{HT}_{1 \mathrm{~A}}$-autoreceptor antagonist ameliorated the therapeutic efficacy in depressive patients. Taken together, neurochemical approaches using microdialysis can contribute not only to clarification of the physiological role of the serotonergic neuronal systems but also might be a powerful pharmacological approach for the development of therapeutic strategies.
\end{abstract}

Keywords: Serotonin, Microdialysis, Autoreceptor, Heteroreceptor, Psychiatric disorder

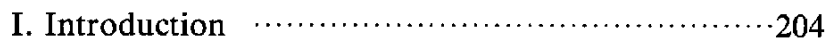

II. Methodological considerations for microdialysis $\cdots 204$

III. Functional regulation of 5-HT release via autoreceptors and heteroreceptors 205

III-1. 5-HT receptors

5- $\mathrm{HT}_{\mathrm{IA}}$ receptor

$5-\mathrm{HT}_{1 \mathrm{~B}}\left(5-\mathrm{HT}_{1 \mathrm{D}}\right)$ receptor

$5-\mathrm{HT}_{2}$ receptor

$5-\mathrm{HT}_{3}$ receptor

III-2. Noradrenaline receptors

III-3. Opioid receptors
III-4. Dopamine receptors

IV. Modulation of neurotransmitter release via 5-HT receptors

IV-1. Noradrenaline release

IV-2. Dopamine release

IV-3. Acetylcholine release

V. Possible role of serotonergic nervous systems in

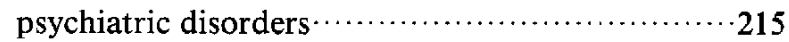

V-1. Major depression

V-2. Schizophrenia

VI. Conclusion 


\section{Introduction}

Serotonergic neurons originating from the raphe nucleus project expansively throughout the central nervous system. It is well-known that central serotonin (5hydroxytryptamine, 5-HT) is involved in physiological functions such as nociception, sleep, feeding behavior, emotion and neuroendocrine function. 5-HT has been the focus of interest for investigating the pathogenesis of emotional disorders such as anxiety and depression. Various neurochemical parameters, i.e., synthesis, turnover and release, of 5-HT have been used to explore serotonergic neuronal activity. Among these indices, 5HT release has been examined by two major in vitro experimental systems: synaptosomes and slices of brain tissues. Based on the results of these in vitro experiments, it is accepted that 5-HT release is regulated not only by autoreceptors but also by presynaptic heteroreceptors $(1-4)$.

In vivo attempts have been made to determine extracellular endogenous 5-HT levels by application of microdialysis. At present, this method is coupled with sensitive high-performance liquid chromatography (HPLC) systems and used extensively as a reliable neurochemical tool (5-7). Evidence for the presence of functional presynaptic regulation on 5-HT release in vivo consists of three observations: i) agonists produce increases or decreases in 5-HT release, ii) selective antagonists prevent or cancel out the agonist-induced action, and iii) anatomical or molecular biological evidence for the existence of the responsible receptors that are located on serotonergic nerve terminals. Although results obtained in vivo do not always agree with those in vitro, microdialysis studies may be able to reveal the existence of not only local regulation of 5-HT release but also the global cross-talk between 5-HT neurons and other neuronal systems that could not be examined easily in in vitro.

This review represents an attempt to overview the functional interactions between 5-HT and other neurotransmitters (or neuromodulators) as studied by in vivo microdialysis. For this purpose, the following points are focused upon: i) regulation of 5-HT release via autoreceptors and presynaptic heteroreceptors, ii) modulation of release of principal neurotransmitters; i.e., noradrenaline (NA), dopamine (DA) and acetylcholine (ACh) through 5-HT receptors, and iii) for evaluation of the pathophysiological significance of serotonergic neurons, possible roles of 5-HT in psychiatric disorders, especially depression and schizophrenia, are reviewed and discussed from the viewpoint of new strategies for clinical treatments.

\section{Methodological considerations for microdialysis}

Early attempts to measure the endogenous neurotransmitter levels by the push-pull methods were followed by their detection in perfusates through dialysis membranes. Subsequently, microdialysis techniques have been developed based on advances of HPLC analytical systems, and this has became a commonly used neurochemical tool. The microdialysis method has many characteristics that make it superior to previous neurochemical approaches. The most distinctive advantage is that it allows monitoring of the extracellular neurotransmitter itself in conscious animals during behavioral observations. Local administration of drugs via dialysis probes without physical stress, furthermore, can allow separate manipulation of cell body and terminal activity. A recently developed modified microdialysis probe, that has an external can-

\footnotetext{
Abbreviations used are (in alphabetical order): ACh, acetylcholine; DA, dopamine; DAGO, [D-Ala ${ }^{2}, N$-methyl-Pen ${ }^{4}, \mathrm{Gly}^{5}$-ol]enkephalin; DC, diencephalon; DPDPE, [D-Pen ${ }^{2}, \mathrm{D}-\mathrm{Pen}^{5}$ ] enkephalin; DRN, dorsal raphe nucleus; GABA, $\gamma$-aminobutyric acid; 5-HIAA, 5-hydroxyindole-3acetic acid; HPLC, high-performance liquid chromatography; 5-HT, serotonin (5-hydroxytryptamine); LC, locus coeruleus; MAO, monoamine oxidase; MDMA, 3,4-methylenedioxymethamphetamine; 2-Me-5-HT, 2-methylserotonin; 5-MeO-DMT, 5-methoxy- $N, N$-dimethyltryptamine; MRN, median raphe nucleus; NA, noradrenaline; NAC, nucleus accumbens; 6-OHDA, 6-hydroxydopamine; 8-OH-DPAT, 8-hydroxy-2-(di- $n$ propylamino)tetralin; SN, substantia nigra; TTX, tetrodotoxin; VTA, ventral tegmental area.
}

Abbreviations for drugs and other chemicals (in alphabetical order): BIMU 1, endo- $N$-(8-methyl-8-azabicyclo[3.2.1]oct-3-yl)-2,3-dihydro-3ethyl-2-oxo-1H-benzimidazole-1-carboxamide; BIMU 8, endo- $N$-(8-methyl-8-azabicyclo[3.2.1]oct-3-yl)-2,3-dihydro-(1-methyl)ethyl-2-oxo-1Hbenzimidazole-1-carboxamide; CGS 12066B, 7-trifluoromethyl-4 (4-methyl-1-piperazinyl)-pyrrolo[1,2-a]quinoxaline; CP-93,129, 3-(1,2,5,6-tetrahydropyrid-4-yl)pyrrolo[3,2-b]-pyrid-5-one; mCPBG, 1-( $m$-chlorophenyl)biguanide; mCPP, $m$-chlorophenylpiperazine; DOB, 1-(2,5-dimethoxy-4-bromophenyl)-2-aminopropane; DOI, 1-(2,5-dimethoxy-4-iodophenyl)-2-aminopropane; GBR 12909, 1-[2-(bis(4-fluorophenyl)methoxy)ethyl]-4-(3-phenylpropyl)piperazine; MDL 72222, 3-tropanyl-3,5-dichlorobenzoate; MDL 72394, (E)- $\beta$-fluoromethyline-m-tyrosine; NAN-190, 1-(2-methoxyphenyl)-4-[4-(2-phthalimido)butyl]piperazine; Org 3770, 1,2,3,4,10,14b-hexahydro-2-methylpyrazino[2,1-a]pyrido[2,3-c][2]benzapepine; ( \pm )-PPHT, ( \pm )-2-( $N$-phenylethyl- $N$-propyl)amino-5-hydroxytetralin; RU 24969, 5-methoxy-3-(1,2,3,6-tetrahydro-4-pyridinyl)-1Hindole; SKF-38393, 1-phenyl-2,3,4,5-tetrahydro-(1H)-3-benzazepine-7,8-diol; TFMPP, $N$-(3-trifluoromethylphenyl)piperazine; U-69593, $(5 \alpha, 7 \alpha, 8 \hat{\beta})-(+)-N$-methyl- $N$-[7-(1-pyrrolidinyl)-1-oxaspiro[4.5]dec-8-yl]-benzeneacetamide; UK 14,304, 5-bromo- $N$-(4,5-dihydro-1 $H$-imidazol2-yl)-6-quinoxalinamine; WAY 100135, $N$-tert-butyl 3-4-(2-methoxyphenyl) piperazine-1-yl-2-phenylpropanamide dihydrochloride. 
nula attached near its tip, can facilitate the assessment of application of compounds such as proteins, peptides and toxins that could not penetrate previous dialysis membranes (8).

The in vivo microdialysis method has, however, several technical problems. Firstly, it is not able to detect neurochemical changes in short time periods because of the low concentrations of extracellular neurotransmitters, especially 5-HT and NA levels. Secondly, the insertion of the probe causes tissue damage, resulting in the contamination by non-synaptic sources such as glial cells and platelets. With regards to the first problem, it is possible to shorten the sampling time periods by increasing the sensitivity of the assay system by usage of microbore HPLC-columns $(9,10)$. With respect to the second problem, there are several criteria with which to confirm whether extracellular neurotransmitter levels are neuronal in origin. The essential criterion is the demonstration that the dialysate neurotransmitter levels are either tetrodotoxin (TTX)-sensitive or $\mathrm{Ca}^{2+}$-dependent. The second is to examine whether neurotransmitter levels are enhanced by increasing perfused $\mathrm{K}^{+}$concentration or by electrical stimulation of their pathways.

With regard to 5-HT release, it is difficult to determine the basal output, especially in the case of measuring dialysate 5-HT levels reduced after drug administration, because of their extremely low concentrations in the perfusate. Therefore, 5-HT levels evoked by $\mathbf{K}^{+}$or electrical stimulation are often evaluated as 5-HT release from nerve terminals. Electrical stimulation appears to be limited by the conditions under anesthesia. It is generally accepted that anesthesia has an inhibitory effect on neurotransmitters (11), and the release of neurotransmitters has been shown to be influenced by various kinds of anesthesia (12). Basal 5-HT levels without $\mathrm{K}^{+}$or electrical stimulation are often determined in the presence of a 5-HT-uptake inhibitor to increase synaptic levels. However, 5-HT-uptake inhibitor citalopram by itself was shown to affect 5-HT-induced pharmacological responses (10). At present, it is difficult to determine the spontaneous 5-HT levels over periods of minutes or seconds. It is expected that the development of assay systems $(9,10)$ and/or improvement of dialysis probes (7) will in the near future allow monitoring of 5-HT levels without uptake inhibitors or $\mathrm{K}^{+}$stimulation over short time periods.

A major metabolite of 5-HT, 5-hydroxyindole-3-acetic acid (5-HIAA), is determined as an indicator of 5-HT neurotransmission in neurochemical methods such as in vivo votammetry (7). Levels of 5-HIAA in the dialysate are several hundred times higher than those of 5-HT itself; however, neither local perfusion of TTX nor electrical stimulation affected dialysate metabolite levels $(13,14)$. Following $\mathrm{K}^{+}$stimulation, 5-HIAA output was decreased slightly $(11,15)$ or unaltered $(16,17)$, suggesting that the majority of the extracellular metabolite levels might reflect intraneuronal metabolism or other non-neuronal processes $(11,14,15)$. Dialysate 5-HIAA levels may be a poor indicator of serotonergic neuronal activity, at least in microdialysis studies. Therefore, this review focused only on the changes in dialysate 5-HT levels.

\section{Functional regulation of 5-HT release via autorecep- tors and heteroreceptors}

The principal focus of this section is to discuss whether 5-HT release is functionally or physiologically regulated via autoreceptors and/or presynaptic heteroreceptors. In addition to autoreceptors, 5-HT receptors sensitive to endogenous 5-HT release are also reviewed. Heteroreceptors that are activated by neurotransmitters (or neuromodulators) from adjacent terminals, neighboring cells or blood-borne substances are described with a focus on studies using in vivo microdialysis. With regard to other neurotransmitters such as $\mathrm{ACh}$, histamine and $\gamma$ aminobutyric acid (GABA)-mediated regulation of 5-HT release, brief reviews will be provided $(2,4)$.

\section{III-1. 5-HT receptors}

5-HT $T_{1 A}$ receptor (Table 1)

5-HT release is subject to regulation by a negative feedback mechanism, which is mediated by two types of autoreceptors; one is localized on somatodendrites in the raphe nuclei and the other exists presynaptically on the terminals of serotonergic neurons. Autoradiographic studies have revealed a very high density of $5-\mathrm{HT}_{1 \mathrm{~A}}$ binding sites in the raphe nuclei (18). Application of $5-\mathrm{HT}_{1 \mathrm{~A}^{-}}$ receptor agonists directly into this area leads to reductions in the firing rate of 5-HT neurons $(19,20), 5-\mathrm{HT}$ synthesis and turnover $(21,22)$. Microdialysis studies have also provided evidence that the systemic administration of 8-hydroxy-2-(di- $n$-propylamino)tetralin (8-OHDPAT) and other putative $5-\mathrm{HT}_{1 \mathrm{~A}}$ agonists reduces $5-\mathrm{HT}$ release from the rat hippocampus and striatum (23-26). However, local administration of 8-OH-DPAT into nerve terminal areas, namely, the hippocampus or striatum, did not affect 5-HT release (26). On the other hand, local infusion of this drug into the raphe nucleus reduced 5-HT release from the ventral hippocampus and striatum (13, 22). These results indicate that $5-\mathrm{HT}_{1 \mathrm{~A}}$ receptors in the raphe nuclei act as somatodendritic autoreceptors to decrease the 5-HT release from nerve terminals.

Morphological and biochemical studies have suggested that the dorsal raphe nucleus (DRN) and median raphe nucleus (MRN) topographically innervated different brain regions $(27,28)$. Kreiss and Lucki $(26)$ reported that local perfusion of 8-OH-DPAT into the DRN produced 
decreases in the dialysate 5 -HT release from the striatum, but not from the hippocampus, while intra-MRN application of this drug reduced that from the hippocampus. Thus, the reduction of 5-HT release from the hippocampus and striatum is mediated by activation of somatodendritic 5- $\mathrm{HT}_{1 \mathrm{~A}}$ autoreceptors in DRN-striatum and MRN-hippocampus serotonergic neurons, respectively. With regards to the differences between these results and those of other reports showing that local application of 8-OH-DPAT into the DRN produced decreases in 5HT release from the ventral hippocampus $(13,22)$, Kreiss and Lucki suggested that large volume of injection might cause diffusion of this drug from the DRN to the adjacent MRN (26). On the other hand, local administration of a selective antagonist for 5-HT $1 \mathrm{~A}$ receptors, WAY 100135 ( $N$-tert-butyl 3-4-(2-methoxyphenyl) piperazine-1-yl-2phenylpropanamide dihydrochloride) (29), into the DRN did not affect the 5-HT output in the striatum (30), suggesting that $5-\mathrm{HT}_{1 \mathrm{~A}}$ autoreceptors did not tonically inhibit 5-HT release.

The origin of extracellular 5-HT itself in the raphe region, however, is less clear. Adell et al. (31) showed that local perfusion of 8-OH-DPAT into the raphe regions failed to decrease the dialysate 5-HT levels in the somatodendritic area. Moreover, despite a large increase in somatodendritic 5-HT output by high $\mathrm{K}^{+}$stimulation, dialysate 5 -HT levels were not affected by either removal of $\mathrm{Ca}^{2+}$ or perfusion of TTX. The authors therefore speculated that the somatodendritic 5-HT may not be regulated by $5-\mathrm{HT}_{1 \mathrm{~A}}$ receptors and may possibly originate from a cytoplasmic pool. On the other hand, Bosker et al.
(32) showed recently that both systemic and local-MRN administration of 8-OH-DPAT produced decreases in 5HT output from the MRN, and furthermore, local infusion of TTX into the MRN decreased 5-HT in this region. These findings indicate the possibility that somatodendritic 5-HT levels, at least in the MRN, may be subject to a local negative feedback mechanism through $5-\mathrm{HT}_{1 \mathrm{~A}}$ autoreceptors.

\section{$5-H T_{I B}\left(5-H T_{I D}\right)$ receptor (Table 2$)$}

Terminal 5-HT autoreceptors that mediate negative feedback regulation of 5-HT release have been identified in several mammalian brain regions. In vitro studies using synaptosomes and slices of rat cortex $(33,34)$, hippocampus (35) and cerebellum (36) led to the conclusion that these receptors belong to the $5-\mathrm{HT}_{1 \mathrm{~B}}$ subtype. Microdialysis studies showed that systemic or local administration of the 5- $\mathrm{HT}_{1 \mathrm{~B}}$-receptor agonists RU 24969 (5-methoxy-3(1,2,3,6-tetrahydro-4-pyridinyl)- $1 H$-indole) and TFMPP ( $N$-(3-trifluoromethylphenyl)piperazine) decreased 5-HT release from the rat frontal cortex and hippocampus (23, $37,38)$. However, these agonists lack selectivity as agonists for 5-HT ${ }_{1 \mathrm{~B}}$ receptors (39). In fact, RU 24969 and TFMPP increased 5-HT release from the rat diencephalon (DC) (40), which is consistent with in vitro data in the hypothalamus (41) and the hippocampus (42). With regard to this observation, RU 24969 and TFMPP may interact with the uptake carrier to enhance extracellular levels of 5-HT because these drug-induced increases in 5HT release were blocked by the 5-HT-uptake inhibitors imipramine and fluoxetine, but not by the autoreceptor

Table 1. Effects of 5-HT $\mathrm{HA}_{1 \mathrm{~A}}$-autoreceptor agonists on 5-HT release from rat brain regions determined by in vivo microdialysis

\begin{tabular}{|c|c|c|c|c|c|}
\hline $\begin{array}{l}5 \text { - } \mathrm{HT}_{1 \mathrm{~A}} \text {-receptor } \\
\text { agonists }\end{array}$ & $\begin{array}{l}\text { Systemic } \\
\text { administration }\end{array}$ & $\begin{array}{l}\text { Local } \\
\text { administration }\end{array}$ & $\begin{array}{l}\text { Hippo- } \\
\text { campus }\end{array}$ & Striatum & Ref. \\
\hline \multirow[t]{12}{*}{ 8-OH-DPAT } & $0.1-1 \mathrm{mg} / \mathrm{kg}$, i.p. & & $\downarrow$ & $\checkmark$ & 26 \\
\hline & $5-250 \mu \mathrm{g} / \mathrm{kg}, \mathrm{s} . \mathrm{c}$. & & $\downarrow$ & & 23 \\
\hline & $0.1 \mathrm{mg} / \mathrm{kg}$, i.p. & & $\downarrow$ & $\checkmark$ & 25 \\
\hline & & $1 / \ell \mathrm{M}$ & r & - & 26 \\
\hline & & into dorsal raphe nucleus & & & \\
\hline & & $3.2 \mu \mathrm{g}$ & $\rightarrow$ & $\downarrow$ & 26 \\
\hline & & $0.5-2.5 \mu \mathrm{g}$ & $\downarrow$ & & 10,22 \\
\hline & & $0.5 \mu \mathrm{g}$ & & $\downarrow$ & 25 \\
\hline & & into median raphe nucleus & & & \\
\hline & & $0.5 \mu \mathrm{g}$ & $\downarrow$ & $\rightarrow$ & 25 \\
\hline & & $3.2 \mu \mathrm{g}$ & $\downarrow$ & $>$ & 26 \\
\hline & & $30 \mathrm{nM}$ & $\downarrow$ & & 32 \\
\hline Buspirone & $5 \mathrm{mg} / \mathrm{kg}$, s.c. & & $\downarrow$ & & 23 \\
\hline Isparirone & $5 \mathrm{mg} / \mathrm{kg}, \mathrm{s.c}$. & & $\downarrow$ & & 23 \\
\hline Gespirone & $5 \mathrm{mg} / \mathrm{kg}, \mathrm{s.c}$ & & $\downarrow$ & & 23 \\
\hline
\end{tabular}

$\uparrow$ increase, $\downarrow$ decrease, $\rightarrow$ no effect. 
antagonist methiothepine (42). This speculation was supported by in vitro data showing that TFMPP inhibited the uptake of $\left[{ }^{3} \mathrm{H}\right] 5-\mathrm{HT}$ into synaptosomes (43). On the other hand, Hjorth and Tao (44) showed that the putatively specific 5 - $\mathrm{HT}_{1 \mathrm{~B}}$-receptor agonist CP-93,129 (3(1,2,5,6-tetrahydropyrid-4-yl)pyrrolo[3,2-b]pyrid-5-one) decreased dialysate 5-HT release both in the presence and absence of citalopram. Thus, the functional inhibitory regulation of 5-HT release through presynaptic 5-HT receptors likely occurs in vivo.

Both systemic and local administration of the 5$\mathrm{HT}_{1 \mathrm{~A} / 1 \mathrm{D}}$-receptor agonist 5-carboxamidotryptamine produced decreases in dialysate 5-HT levels from the guinea pig frontal cortex (45). This inhibition appeared to be caused by activation of $5-\mathrm{HT}_{1 \mathrm{D}}$ receptors, because inhibitory presynaptic 5-HT autoreceptors of guinea pig, human and calf have been identified as the $5-\mathrm{HT}_{1 \mathrm{D}}$ subtype (46). This suggested that $5-\mathrm{HT}_{1 \mathrm{D}^{-}}$and $5-\mathrm{HT}_{\mathrm{LB}}$ receptors are species equivalents, since they have the same regional distribution and affect the same second messenger system (47). Starkey and Skingle (48) recently showed, using fast cyclic voltammetry, that $5-\mathrm{HT}_{1 \mathrm{D}}$-receptor agonist sumatriptan produced inhibition of 5 -HT release from the guinea pig DRN, which was blocked by a 5$\mathrm{HT}_{1 \mathrm{D}}$ antagonist. Thus, the 5-HT $\mathrm{HD}_{1 \mathrm{D}}$ receptors may exist not only in the nerve terminals but also in the DRN as $5-\mathrm{HT}_{1 \mathrm{~A}}$ autoreceptors. Molecular biological studies have revealed that there are two subtypes of human $5-\mathrm{HT}_{1 \mathrm{D}}$ receptors; i.e., $5-\mathrm{HT}_{1 \mathrm{D} \alpha^{-}}$and $5-\mathrm{HT}_{1 \mathrm{D}^{3}}$ receptors. The latter receptor subtype is a homologue of the rat $5-\mathrm{HT}_{1 \mathrm{~B}}$ receptors sharing $96 \%$ amino acid sequence similarity in the transmembrane domains $(49,50)$. The existence and physiological roles of terminal autoreceptors, therefore, may be engaged in both the development of both more

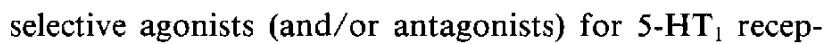
tors and in molecular pharmacological research.

\section{5- $\mathrm{HT}_{2}$ receptor (Table 3 )}

$5-\mathrm{HT}_{2}$ receptors are now subclassified into three families based on the results of pharmacological and molecular biological studies $(51,52)$. The $5-\mathrm{HT}_{1 \mathrm{IC}}$ receptor has been classified as belonging to the $5-\mathrm{HT}_{2}$-receptor family because of similarity in the signal transduction system and has thus been renamed the $5-\mathrm{HT}_{2 \mathrm{C}}$ receptor. $5-\mathrm{HT}_{2}$ receptors are further subdivided into $5-\mathrm{HT}_{2 \mathrm{~A}^{-}}$and $5-\mathrm{HT}_{2 \mathrm{~B}^{-}}$ receptor subtypes. The $5-\mathrm{HT}_{2 \mathrm{~A}}$ receptor is a new designation recently introduced to describe the "historical" 5$\mathrm{HT}_{2}$ receptor (52). In this review, however, the term 5$\mathrm{HT}_{2}$ receptor and $5-\mathrm{HT}_{1 \mathrm{C}}$ receptor are used following the description in the literature.

5-HT neuronal activity was inhibited by activation of 5- $\mathrm{HT}_{2}$ receptors: Systemic application of the 5- $\mathrm{HT}_{2}-$ receptor agonist DOI (1-(2,5-dimethoxy-4-iodophenyl)-2aminopropane) inhibited the dorsal raphe neuronal 5-HT firing rate $(53,54)$. DOI also produced reduction of dialysate 5-HT release from the rat frontal cortex; however, local administration of this drug into the frontal cortex produced no changes in 5 -HT release $(54,55)$. Since the neuronal changes in DRN lead to corresponding changes in 5-HT release of the terminal regions, the decreased 5HT release may be a result of the reduction in the firing activity in the dorsal raphe. Furthermore, dialysate 5-HT release from the rat nucleus accumbens (NAC), which is known to have a moderate density of $5-\mathrm{HT}_{2}$ binding sites, was increased by systemic administration of the $5-\mathrm{HT}_{2-}$ receptor antagonist (53). Thus, 5-HT release might be tonically mediated by $5-\mathrm{HT}_{2}$ receptors.

\section{$5-\mathrm{HT}_{3}$ receptor (Table 3 )}

5-HT release is facilitated by activation of $5-\mathrm{HT}_{3}$ receptors. Local administration of the $5-\mathrm{HT}_{3}$-receptor agonist 2-methylserotonin (2-Me-5-HT) produced increases in dialysate 5-HT release from the rat hippocam-

Table 2. Effects of 5-HT 18 -autoreceptor agonists on 5-HT release from rat brain regions determined by in vivo microdialysis

\begin{tabular}{|c|c|c|c|c|c|}
\hline $\begin{array}{l}5-\mathrm{HT}_{1 \mathrm{~B}} \text {-receptor } \\
\text { agonists }\end{array}$ & $\begin{array}{l}\text { Systemic } \\
\text { administration }\end{array}$ & $\begin{array}{l}\text { Local } \\
\text { administration }\end{array}$ & $\begin{array}{l}\text { Hippo- } \\
\text { campus }\end{array}$ & $\begin{array}{l}\text { Dien- } \\
\text { cephalon }\end{array}$ & Ref \\
\hline \multirow[t]{6}{*}{ RU 24969} & 1 and $5 \mathrm{mg} / \mathrm{kg}$, i.p. & & $\downarrow$ & & 38 \\
\hline & $2.5 \mathrm{mg} / \mathrm{kg}$, i.p. & & & $\downarrow$ & 40 \\
\hline & $0.25-5 \mathrm{mg} / \mathrm{kg}$, s.c. & & $\downarrow$ & & 23 \\
\hline & & 0.1 and $1 \mu \mathrm{M}$ & $\downarrow$ & & 38 \\
\hline & & $0.1 \mu \mathrm{M}$ & $\downarrow$ & & 44 \\
\hline & & 1 and $5 \mu \mathrm{M}$ & & $\uparrow$ & 40 \\
\hline \multirow[t]{2}{*}{ TFMPP } & $2.5-10 \mathrm{mg} / \mathrm{kg}$, i.p. & & & $\uparrow$ & 40 \\
\hline & & 10 and $50 \mu \mathrm{M}$ & & $\uparrow$ & 40 \\
\hline CP-93,129 & & 3 and $10 \mu \mathrm{M}$ & $\downarrow$ & & 44 \\
\hline
\end{tabular}

$\uparrow$ increase, $\downarrow$ decrease. 
pus, which was antagonized by the $5-\mathrm{HT}_{3}$-receptor antagonist MDL 72222 (3-tropanyl-3,5-dichlorobenzoate) (38). This $5-\mathrm{HT}_{3}$-receptor antagonist by itself did not affect 5-HT release, suggesting that the facilitatory effect is not tonically mediated by endogenous $5-\mathrm{HT}$. This raises the question of whether $5-\mathrm{HT}_{3}$ - and/or $5-\mathrm{HT}_{2}$ receptors are located on 5-HT nerve terminals as autoreceptors. In vitro studies using synaptosome preparations of rat spinal cord (56) and guinea pig hypothalamus (57) showed the lack of a facilitatory effect through $5-\mathrm{HT}_{3}$ receptors, despite the positive response in guinea pig brain slices ( 58 , 59). These reports suggested that the 5-HT 3 receptors mediating 5-HT release are not located on 5-HT nerve terminals.

At present, 5- $\mathrm{HT}_{2}$ - and 5- $\mathrm{HT}_{3}$-receptor antagonists are thought to play a functional role in antipsychotic $(60)$ and anxiolytic effects $(61-63)$. It is important to determine whether 5 -HT release is regulated physiologically by these receptors; however, the precise mechanism and location of these receptors regulating 5 -HT release still remain unclear.

\section{III-2. Noradrenaline receptors (Table 4)}

Numerous in vitro studies have provided evidence for the existence of $\alpha_{2}$-adrenoceptors on 5-HT nerve terminals in various brain regions in rats $(64-66)$, rabbits $(66$, $67)$ and humans (68). These reports revealed that the 5 HT release from nerve terminals was negatively regulated not only by $5-\mathrm{HT}_{1 \mathrm{~B}}$ (or $5-\mathrm{HT}_{1 \mathrm{D}}$ ) autoreceptors but also by $\alpha_{2}$-heteroreceptors. Tao and Hjorth (69), using microdialysis methods, showed that the systemic administration of $\alpha_{2}$-adrenoceptor agonists reduced the spontaneous 5-HT release from the rat ventral hippocampus, which was abolished by the $\alpha_{2}$-adrenoceptor antagonist idazoxan. Their findings of the inhibitory mechanism of 5-HT release via $\alpha_{2}$-heteroreceptors in vivo extended the observations made in the in vitro studies. Anatomical studies have indicated that the serotonergic neurons in the rat hippocampus originate mainly from the raphe nucleus. The systemic administration of clonidine, therefore, may change the hippocampal 5-HT levels due not only to the activation of $\alpha_{2}$-heteroreceptors but also the reduction in the firing rate of the raphe nucleus. In fact, noradrenergic neurons originating from the locus coeruleus (LC) influence 5-HT release and neuronal firing activity in the DRN by inhibitory $\alpha_{2}$-adrenoceptors (70) or facilitatory $\alpha_{1}$-adrenoceptors (71). However, local administration of clonidine or UK 14,304 (5-bromo- $N$-(4,5dihydro- $1 H$-imidazol-2-yl)-6-quinoxalinamine), a selective $\alpha_{2}$-adrenoceptor agonist, into the rat hippocampus decreased the spontaneous 5-HT output (72) and the $\mathrm{K}^{+}$. evoked 5 -HT release $(16,17)$. These inhibitions were also observed in noradrenergic-lesioned rats $(16,17)$, further supporting that the inhibitory $\alpha_{2}$-adrenoceptors are located on 5-HT nerve terminals. These presynaptic $\alpha_{2^{-}}$ heteroreceptors appeared to be coupled with $G$ proteins because the UK 14,304-induced inhibitory effect was abolished by pretreatment with pertussis toxin, which is a substrate of $G$ proteins (17). This in vivo result was in agreement with that of a previous in vitro study (65).

The tonic inhibition by endogenous NA on 5-HT release was examined in numerous in vitro experiments, but the results were inconsistent; tonic inhibition via $\alpha_{2}$ heteroreceptors has been reported in brain tissues of humans $(68,73)$, rats $(73)$ and rabbits (74), while several reports showed a lack of such a tonic inhibitory effect $(75-77)$. Recently, in vivo electrophysiological studies (78) have demonstrated that small doses of clonidine (2 and $10 \mu \mathrm{g} / \mathrm{kg}$, i.v.) enhanced $5-\mathrm{HT}$ release, which was abolished by NA denervation and yohimbine. High doses of clonidine (100 and $400 \mu \mathrm{g} / \mathrm{kg}$, i.v.) decreased 5-HT neurotransmission, and this effect was affected by neither

Table 3. Effects of 5-HT release by $5-\mathrm{HT}_{2}-$ and $5-\mathrm{HT}_{3}$ receptors from rat brain regions determined by in vivo microdialysis

\begin{tabular}{|c|c|c|c|c|c|c|}
\hline $\begin{array}{l}\text { 5-HT-receptor } \\
\text { agents }\end{array}$ & $\begin{array}{l}\text { Systemic } \\
\text { administration }\end{array}$ & $\begin{array}{l}\text { Local } \\
\text { administration }\end{array}$ & $\begin{array}{l}\text { Hippo- } \\
\text { campus }\end{array}$ & Cortex & $\begin{array}{l}\text { Nucleus } \\
\text { accumbens }\end{array}$ & Ref. \\
\hline \multicolumn{7}{|l|}{ 5- $\mathrm{HT}_{2}$ agonist } \\
\hline \multirow[t]{4}{*}{ DOI } & $100 \mu \mathrm{g} / \mathrm{kg}, \mathrm{i}, \mathrm{v}$ & & & $\downarrow$ & & 54,55 \\
\hline & & 1,10 and $100 \mathrm{ng}$ & & $\rightarrow$ & & 54 \\
\hline & & into dorsal raphe nucleus & & & & \\
\hline & & $1 \mathrm{ng}$ & & $\downarrow$ & & 55 \\
\hline \multicolumn{7}{|c|}{$5-\mathrm{HT}_{2}$ antagonist } \\
\hline Ritanserin & $0.63 \mathrm{mg} / \mathrm{kg}$, i.p. & & & & $\uparrow$ & 53 \\
\hline \multicolumn{7}{|l|}{$5-\mathrm{HT}_{3}$ agonist } \\
\hline 2-Me-5-HT & & $0.1-10 \mu \mathrm{M}$ & $\uparrow$ & & & 38 \\
\hline
\end{tabular}

$\uparrow$ increase, $\downarrow$ decrease, $\rightarrow$ no effect. 
NA denervation nor yohimbine. These findings indicate that a low dose of clonidine may preferentially activate $\alpha_{2}$-autoreceptors on NA neurons and then reduce the tonic inhibitory effect of endogenous NA on $\alpha_{2}$-heteroreceptors, whereas a high dose may activate $\alpha_{2}$-heteroreceptors directly. They noticed that in the in vitro experiments, endogenous NA may hardly reach the $5-\mathrm{HT}$ nerve terminal as a result of being washed away by the superfusion fluid. Therefore, in vivo experiments may be more suitable for examination of tonic inhibition. In fact, microdialysis studies showed that $\alpha_{2}$-adrenoceptor antagonists increased 5-HT release $(79,80)$. Furthermore, we have recently observed that dialysate $5-\mathrm{HT}$ release from the rat hippocampus is increased after systemic administration of idazoxan $(5 \mathrm{mg} / \mathrm{kg}$, i.p.) (unpublished data). These results strongly support that the tonic inhibitory regulation of 5-HT release by endogenous NA exists in vivo.

The heterogeneity of $\alpha_{2}$-adrenoceptors is well-known. At present, $\alpha_{2}$-adrenoceptors can be divided into at least four distinct subcategories: $\alpha_{2 \mathrm{~A}^{-}}, \alpha_{2 \mathrm{~B}^{-}}, \alpha_{2 \mathrm{C}^{-}}$and $\alpha_{2 \mathrm{D}^{-}}$-receptors (81). Several in vitro studies have revealed that $\alpha_{2}$ autoreceptors and heteroreceptors are not identical based on results showing different potencies of clonidine or different effects of the (-)enantiomer of mianserin (82, 83). Recent evidence (66) has suggested that $\alpha_{2}$-auto- and $\alpha_{2}$-heteroreceptors are pharmacologically identical, but differ depending on the species; i.e., presynaptic $\alpha_{2}$-autoas well as $\alpha_{2}$-heteroreceptors are the $\alpha_{2 \mathrm{D}}$-subtype of rats and the $\alpha_{2 \mathrm{~A}}$-subtype of rabbits.

\section{III-3. Opioid receptors (Table 5)}

A functional linkage between opioids and 5-HT neuronal systems has been proposed based on neurochemical evidence. For instance, serotonergic neurons were involved in the analgesic effects of opioids (84), and 5-HT turnover was influenced by acute and chronic administration of morphine (85). However, data concerning the regulation of 5-HT release through opioid receptors are inconsistent. Several microdialysis studies showed that systemic administration of morphine enhanced extracellular 5-HT levels in the rat DC and hippocampus (86, 87). These results are consistent with the biochemical results that morphine produced increases in 5-HT synthesis $(88,89)$ and tryptophan hydroxylase activity $(90)$. Matos et al. (91), however, observed that the same dose of morphine $(10 \mathrm{mg} / \mathrm{kg}$, i.p.) did not increase the dialysate 5-HT from the rat dorsal spinal cord. In vitro experiments using rat spinal cord synaptosomes also showed that morphine had no effect (92).

Radioligand binding studies provided evidence that 5HT nerve terminals in the rat striatum are endowed with opiate receptors (93). $\mathrm{K}^{+}$-evoked 5-HT release from rat hippocampus was inhibited both by [D-Ala ${ }^{2}, N$-methyl$\mathrm{Pen}^{4}, \mathrm{Gly}^{5}$-ol]enkephalin (DAGO) and [D-Pen $\left.{ }^{2}, \mathrm{D}-\mathrm{Pen}^{5}\right]$ enkephalin (DPDPE), $\mu$ - and $\delta$-opioid receptor agonists, respectively (94). These findings suggest that the $5-\mathrm{HT}$ release from nerve terminals was negatively regulated by both $\mu$ - and $\delta$-opioid receptors. Passarelli and Costa (94) speculated that $\mu$-and $\delta$-opioid receptors exist in the same membrane of serotonergic nerve terminals. Our studies, however, showed that the $\mathrm{K}^{+}$-evoked 5-HT release from the rat hippocampus was inhibited by local administration of morphine, but not by either DPDPE or U-69593 $((5 \alpha, 7 \alpha, 8 \beta)-(+)-N$-methyl- $N$-[7-(1-pyrrolidinyl)-1-oxaspiro[4.5]dec-8-yl]-benzeneacetamide) ( $\kappa$-opioid receptor agonist) (95). A specific opioid receptor subtype appears to modulate specific neurotransmitter substances in the

Table 4. Effects of $\alpha_{2}$-adrenoceptor agonists and antagonists on 5-HT release from rat brain regions determined by in vivo microdialysis

\begin{tabular}{|c|c|c|c|c|c|}
\hline $\begin{array}{l}\alpha_{2} \text {-Adrenoceptor } \\
\text { agents }\end{array}$ & $\begin{array}{l}\text { Systemic } \\
\text { administration }\end{array}$ & $\begin{array}{l}\text { Local } \\
\text { administration }\end{array}$ & $\begin{array}{l}\text { Hippo- } \\
\text { campus }\end{array}$ & Cortex & Ref. \\
\hline \multicolumn{6}{|l|}{ Agonist } \\
\hline \multirow[t]{5}{*}{ Clonidine } & $0.01-0.3 \mathrm{mg} / \mathrm{kg}$, s.c. & & $\downarrow$ & & 69 \\
\hline & $0.5 \mathrm{mg} / \mathrm{kg}, \mathrm{s} . \mathrm{c}$. & & $\downarrow$ & & 72 \\
\hline & $0.03-0.1 \mu \mathrm{g} / \mathrm{kg}$, i.p. & & & r & 79 \\
\hline & & $10 \mu \mathrm{M}$ & $\downarrow$ & & 72 \\
\hline & & $10 \mu \mathrm{M}$ & $\downarrow *$ & & 16 \\
\hline Jingsongling & $0.1 \mathrm{mg} / \mathrm{kg}$, s.c. & & $\downarrow$ & & 69 \\
\hline UK 14,304 & & $0.1-10 \mu \mathrm{M}$ & $\downarrow *$ & & 17 \\
\hline \multicolumn{6}{|l|}{ Antagonist } \\
\hline Yohimbine & $5 \mathrm{mg} / \mathrm{kg}$, i.p. & & & $\uparrow$ & 79 \\
\hline Org 3770 & $2 \mathrm{mg} / \mathrm{kg}, \mathrm{s} . \mathrm{c}$. & & $\uparrow$ & & 80 \\
\hline
\end{tabular}

$\uparrow$ increase, $\downarrow$ decrease. ${ }^{*}: \mathrm{K}^{+}(120 \mathrm{mM})$-evoked 5-HT release. 
central nervous system. For instance, DA release from the rat and guinea pig brain regions was inhibited by $\kappa$-opioid receptors $(96,97)$, whereas $A C h$ release was inhibited by $\delta$-opioid receptors $(96,98)$. The existence of $\mu$-opioid receptors that inhibited NA release was demonstrated in many studies $(98-100)$. Our findings that the morphineinduced decreases in 5-HT release was antagonized by naltrexone furthermore confirmed that the inhibitory opioid receptors of 5-HT nerve terminals belong to the $\mu$-opioid subtypes.

Despite the evidence that 5-HT release was functionally inhibited by opioid receptors, dialysate 5 -HT concentrations increased after systemic administration of morphine. Different responses to morphine due to the application route was also observed in NA release (100). Tao and Auerbach (87) showed that the microinjection of morphine into the mesencephalic raphe nuclei produced increases in dialysate 5-HT release from the DC. These results suggest the possibility that morphine exerts its effect at the level of 5-HT cell bodies and leads to stimulation of 5-HT neuronal activity. However, 5-HT neuronal discharge was not increased after iontophoretic administration of morphine (101). Therefore, the facilitatory effect of systemic administration of morphine on 5HT release might result from an indirect action by blocking an inhibitory neurotransmitter such as GABA, as well as DA (102) and NA neuronal systems (103).

\section{III-4. Dopamine receptors (Table 6)}

Serotonergic neurons project to the striatum, the substantia nigra (SN) and the ventral tegmental area (VTA), which are the targets and source for the mesencephalic dopaminergic systems $(104,105)$. In addition to the morphological evidence, biochemical $(106,107)$ and behavioral studies $(108,109)$ have suggested that the functional regulation by DA receptors of serotonergic neurons, or vice versa (see later), occurs at the somatodendritic or the terminal level. In vitro experiments showed that DA and the non-selective DA agonist apomorphine stimulated 5HT release from rat nigral slices (110). A major portion of the DA neurons on 5-HT release may not be due to presynaptic DA receptors but due to inhibition of 5-HT uptake, because these DA agents also inhibited $\left[{ }^{3} \mathrm{H}\right]-5-\mathrm{HT}$ uptake sites (111). However, studies using synaptosomes (112) and slices (113) of rat hippocampus suggested the existence of facilitative presynaptic DA receptors located on 5-HT nerve terminals. It remains unclear whether serotonergic neurons possess $\mathrm{DA} \mathrm{D}_{1^{-}}, \mathrm{DA} \mathrm{D}_{2^{-}}$or the recently cloned DA $\mathrm{D}_{3}$-receptors (114). Stimulation of DA $\mathrm{D}_{1}$-receptors leads to activation of adenylate cyclase and formation of c-AMP, while DA $\mathrm{D}_{2}$-receptor stimulation has the opposite effect (115). Neurochemical research has shown that the presynaptic inhibitory DA receptors, which mediate releases of NA (116), ACh (117) and DA (118) (autoreceptors), possess characteristics of the DA $\mathrm{D}_{2}$-subtype. Benkirane et al. (119), however, indicated that the exogenous and endogenous DA caused inhibition of electrically evoked $\left[{ }^{3} \mathrm{H}\right]-5-\mathrm{HT}$ release from the rat substantia nigra by activation of DA $D_{1}$-receptors.

The DRN contains a fairly high density of DA $D_{2-}$ receptors but not DA $D_{1}$-receptors (120). Ferré and Artigas (121) reported, using in vivo microdialysis, that local infusion of apomorphine and the selective $\mathrm{DA} \mathrm{D}_{2}$ receptor agonist produced increases in dialysate 5-HT levels from the DRN. Their group further showed that systemic administration of apomorphine increased 5-HT levels in the DRN, whereas it decreased dialysate 5-HT levels from the striatum (30). Furthermore, the reduction of striatal $5-\mathrm{HT}$ release was abolished by the $5-\mathrm{HT}_{1 \mathrm{~A}}$ antagonist WAY 100135. Based on these findings, they hypothesized the existence of inhibitory dopaminergic control of DRN-striatal neurons in vivo, mediated by increasing 5-HT levels in the DRN, and consequently by increasing somatodendritic $5-\mathrm{HT}_{1 \mathrm{~A}}$-autoreceptor stimulation. Neither locally perfused $\mathrm{DA} \mathrm{D}_{2^{-}}$nor $\mathrm{DA} \mathrm{D}_{1^{-}}$receptor agonists affected 5-HT release from the striatum,

Table 5. Effects of morphine on 5-HT release from rat brain regions determined by in vivo microdialysis

\begin{tabular}{|c|c|c|c|c|c|}
\hline $\begin{array}{l}\text { Systemic } \\
\text { administration }\end{array}$ & $\begin{array}{l}\text { Local } \\
\text { administration }\end{array}$ & $\begin{array}{l}\text { Hippo- } \\
\text { campus }\end{array}$ & $\begin{array}{l}\text { Spinal } \\
\text { cord }\end{array}$ & $\begin{array}{l}\text { Dien- } \\
\text { cephalon }\end{array}$ & Ref. \\
\hline \multicolumn{6}{|l|}{ Morphine } \\
\hline 5 and $10 \mathrm{mg} / \mathrm{kg}$, i.p. & & & $\rightarrow$ & & 91 \\
\hline 5,10 and $50 \mathrm{mg} / \mathrm{kg}$, s.c. & & & & $\uparrow$ & 86 \\
\hline \multirow[t]{5}{*}{$10 \mathrm{mg} / \mathrm{kg}$, s.c. } & & $\uparrow$ & & $\uparrow$ & 87 \\
\hline & $0.1-10 \mu \mathrm{M}$ & $\downarrow *$ & & & 95 \\
\hline & $10 \mu \mathrm{M}$ & & & $\rightarrow$ & 87 \\
\hline & into raphe nucleus & & & & \\
\hline & 1 and $10 \mu \mathrm{g}$ & & & $\wedge$ & 87 \\
\hline
\end{tabular}

$\uparrow$ increase, $\downarrow$ decrease, $\rightarrow$ no effect. ${ }^{*}: \mathrm{K}^{+}(120 \mathrm{mM})$-evoked 5 -HT release. 
indicating that the regulation of 5-HT release through presynaptic DA receptors did not occur, at least in the terminals of the rat striatum (30).

Recently, we observed that locally perfused apomorphine and the DA $D_{2}$-selective agonist $( \pm)$-PPHT $(( \pm)$-2( $N$ - phenylethyl - $N$ - propyl) amino - 5 - hydroxytetralin) increased dialysate 5-HT release from the rat hippocampus. Furthermore, the fact that DA-uptake inhibitor GBR 12909 (1-2-(bis(4-fluophenyl)-methoxy)-ethyl)-4-(3phenyl-propyl)piperazine) produced increases in 5-HT release indicated that 5-HT release was regulated not only by exogenous but also by endogenous DA. Apomorphine- and ( \pm -PPHT-induced increases in 5-HT release was antagonized by the $\mathrm{DA}_{2}$-receptor antagonist $S(-)$ sulpiride, suggesting that $5-\mathrm{HT}$ release was facilitatively regulated by DA $\mathrm{D}_{2}$-receptors. However, $( \pm)$-PPHT failed to increase 5-HT release in NA-lesioned rats pretreated with 6-hydroxydopamine (6-OHDA). Thus, facilitation of 5-HT release through $\mathrm{DA}_{2}$-receptors might be indirectly mediated via noradrenergic neurons (M. Matsumoto et al., unpublished data). These in vivo studies, therefore, suggest that DA receptors that regulate 5-HT release do not exist on the serotonergic nerve terminals.

\section{Modulation of neurotransmitter release via 5-HT receptors}

Anatomical studies demonstrate that 5-HT neurons extend multiple-branched and divergent connections to many target regions that contain other neurotransmitters such as NA, DA and ACh. This neuronal organization led us to predict that 5 -HT by itself can influence the release of other neurotransmitters via presynaptic or somatodendritic 5-HT receptors. In this section, we will review and discuss the physiological significance of 5-HT receptors located on other neurons, especially NA, DA and ACh neurons.

\section{IV-1. Noradrenaline release (Table 7)}

Numerous brain regions are innervated by both serotonergic and noradrenergic neurons originating from the raphe nucleus and LC, respectively. It is generally accepted that central serotonergic neurons exert tonic inhibition on noradrenergic nervous systems based on biochemical studies $(122,123)$. Microdialysis studies showed that the spontaneous NA release from the rat hippocampus was reduced by systemic administration of a 5 $\mathrm{HT}_{2}$-receptor agonist (124). This inhibition appeared to tonically influence NA release because $5-\mathrm{HT}_{2}$-receptor antagonists by themselves increased NA release, at least in conscious rats (125). It is unlikely that $5-\mathrm{HT}_{2}$-receptor agonists act directly on nerve terminals because local perfusion did not affect NA release (124). 5- $\mathrm{HT}_{2}$-receptor agonists may act on LC neurons, which results in a decrease of NA release, because the presence of $5-\mathrm{HT}_{2}$ receptor-mediated inhibitory regulation on NA neuronal firing rate was suggested by the results of a previous study (126)

Recently, we reported that the depolarized NA release by $\mathrm{K}^{+}$stimulation from the rat hippocampus was decreased by both exogenous and endogenous 5-HT. These inhibitory effects were prevented by pretreatment with a $5-\mathrm{HT}_{3}$-receptor antagonist, suggesting that functional inhibitory regulation of NA release by $5-\mathrm{HT}_{3}$ receptors occurs in vivo (127). These findings were consistent with the in vitro observations that the inhibitory effect of 5-HT on $\mathrm{K}^{+}$- or glutamic acid-evoked NA release from rat hypothalamic slices $(128,129)$. It is wellknown that $5-\mathrm{HT}_{3}$ receptors belong to the class of intrinsic channel receptors. The question remains as to why the stimulation of $5-\mathrm{HT}_{3}$ receptors caused decreases in NA

Table 6. Effects of DA-receptor agonists on 5-HT release from rat brain regions determined by in vivo microdialysis

\begin{tabular}{|c|c|c|c|c|c|}
\hline $\begin{array}{l}\text { DA-receptor } \\
\text { agonists }\end{array}$ & $\begin{array}{l}\text { Systemic } \\
\text { administration }\end{array}$ & $\begin{array}{l}\text { Local } \\
\text { administration }\end{array}$ & Striatum & $\begin{array}{l}\text { Dorsal raphe } \\
\text { nucleus }\end{array}$ & Ref. \\
\hline \multirow[t]{3}{*}{ Apomorphine } & & $10 \mu \mathrm{M}$ & $\rightarrow$ & & 30 \\
\hline & & 10 and $100 \mu \mathrm{M}$ & & $\uparrow$ & 121 \\
\hline & $2.8 \mu \mathrm{mol} / \mathrm{kg}$, s.c. & & $\downarrow$ & $\uparrow$ & 30 \\
\hline \multicolumn{6}{|l|}{ DA $D_{1}$-agonist } \\
\hline SKF-38393 & & $10 \mu \mathrm{M}$ & $\rightarrow$ & & 30 \\
\hline \multicolumn{6}{|l|}{ DA $\mathrm{D}_{2}$-agonist } \\
\hline \multirow{2}{*}{\multicolumn{2}{|c|}{ Quinpilole (LY 177,155) }} & $10 \mu \mathrm{M}$ & $\rightarrow$ & & 30 \\
\hline & & $10 \mu \mathrm{M}$ & & $\uparrow$ & 121 \\
\hline
\end{tabular}

$\uparrow$ increase, $\downarrow$ decrease, $\rightarrow$ no effect. 
release. Many proposals could account for the neuronal mechanism based on previous observations; i.e., $5-\mathrm{HT}_{3}$ receptor activation may inhibit neuronal firing rates (130) or $5-\mathrm{HT}_{3}$ receptors may be involved in the modulation of phosphoinositide hydrolysis (131). However, it is most likely that this inhibition through $5-\mathrm{HT}_{3}$ receptors is due to an indirect action via other interneurons such as GABA (132) or DA (133) neuronal systems.

In contrast, some studies have reported the facilitatory effect of 5-HT on the noradrenergic nervous system. Systemic administration of a $5-\mathrm{HT}_{1 \mathrm{~A}}$-receptor agonist, produced increases in dialysate NA from the rat hippocampus (125). These findings are agreement with the previous results that $5-\mathrm{HT}_{1 \mathrm{~A}}$-receptor agonists increased NA turnover as well as the firing rate of LC neurons $(134,135)$. However, a recent electrophysiological study demonstrated that doses of $5-\mathrm{HT}_{1 \mathrm{~A}}$-receptor agonists required for excitation of NA neurons in the rat LC were similar to those capable of reversing amphetamine-induced inhibition of DA neurons in the SN, but not those that depressed 5-HT neurons in the DRN. The authors therefore suggested that facilitation of NA neurons by 5$\mathrm{HT}_{1 \mathrm{~A}}$-receptor agonists may be due to interaction with dopaminergic, rather than serotonergic receptors (136).

On the other hand, Mongeau et al. (137) showed that a relative high concentration of 2-Me-5-HT increased the electrically evoked $\left[{ }^{3} \mathrm{H}\right] \mathrm{NA}$ release from slices of the rat hypothalamus, hippocampus and cortex. They showed that the 5-HT $\mathrm{H}_{2}$-receptor agonist DOI also increased hippocampal NA release. This raises the question of whether $5-\mathrm{HT}_{3}-$ and/or $5-\mathrm{HT}_{2}$ receptors exist on noradrenergic nerve terminals. This has not yet been elucidated; however, a binding study could not show the existence of the $5-\mathrm{HT}_{3}$ heteroreceptors on noradrenergic neurons (138). Recently, Schlicker et al. (139) provided evidence, using mouse cortical slices that $5-\mathrm{HT}_{3}$-receptor agonists such as mCPBG (1-( $m$-chlorophenyl)biguanide) and 2Me-5-HT have $\alpha_{2}$-adrenoceptor antagonistic actions. They noticed, therefore, that careful consideration of the results of experiments designed to identify $5-\mathrm{HT}_{3}$ receptors mediating facilitation of neurotransmitter release is necessary.

\section{IV-2. Dopamine release (Table 8)}

Anatomical studies indicated that 5-HT neurons project from the DRN to DA cell bodies in the VTA and $\mathrm{SN}$ and to the respective projection fields of DA neurons such as NAC and striatum (104). It has been reported that serotonergic nerve terminals make direct synaptic contact with dopaminergic neurons and facilitate dendritic $\mathrm{Ca}^{2+}$ conductance on DA neurons in the SN (140). However, biochemical and electrophysiological studies showed either facilitation or inhibition of DA release in the presence of 5-HT agonists. In vitro experiments using rat striatal or nigral slices showed that 5-HT increased DA release $(141,142)$. Blandina et al. (142) indicated that the

Table 7. Modulation of NA release by 5-HT receptors from rat hippocampus determined by in vivo microdialysis

\begin{tabular}{|c|c|c|c|c|}
\hline $\begin{array}{l}\text { 5-HT-receptor } \\
\text { agents }\end{array}$ & $\begin{array}{l}\text { Systemic } \\
\text { administration }\end{array}$ & $\begin{array}{l}\text { Local } \\
\text { administration }\end{array}$ & $\begin{array}{l}\text { Hippo- } \\
\text { campus }\end{array}$ & Ref. \\
\hline $5-\mathrm{HT}$ & & $0.01-10 \mu \mathrm{M}$ & $\downarrow *$ & 127 \\
\hline Quipazine & $1 \mathrm{mg} / \mathrm{kg}, \mathrm{s} . \mathrm{c}$. & & $\downarrow$ & 124 \\
\hline$p$-Chloroamphetamine & $2 \mathrm{mg} / \mathrm{kg}$, s.c. & & $\downarrow$ & 124 \\
\hline Fluoxetine & & $10 \mu \mathrm{M}$ & $\downarrow *$ & 127 \\
\hline \multicolumn{5}{|l|}{ 5- $\mathrm{HT}_{\mathrm{IA}}$ agonist } \\
\hline 8-OH-DPAT & 0.1 and $1 \mathrm{mg} / \mathrm{kg}$, s.c. & & $\uparrow$ & 125 \\
\hline Buspirone & 1,5 and $10 \mathrm{mg} / \mathrm{kg}$, s.c. & & $\uparrow$ & 125 \\
\hline Ipsapirone & $10 \mathrm{mg} / \mathrm{kg}$, s.c. & & $\uparrow$ & 125 \\
\hline NAN-190 & $0.3 \mathrm{mg} / \mathrm{kg}$, s.c. & & $\uparrow$ & 125 \\
\hline \multicolumn{5}{|l|}{$5-\mathrm{HT}_{2}$ agonist } \\
\hline DOI & 0.2 and $0.5 \mathrm{mg} / \mathrm{kg}$, s.c. & & $\downarrow$ & 124 \\
\hline DOB & $1 \mathrm{mg} / \mathrm{kg}, \mathrm{s} . \mathrm{c}$. & & $\downarrow$ & 124 \\
\hline \multicolumn{5}{|l|}{ 5- $\mathrm{HT}_{2}$ antagonist } \\
\hline Ritanserin & $0.2 \mathrm{mg} / \mathrm{kg}$, s.c. & & $\uparrow$ & 125 \\
\hline ICI 170,809 & $5 \mathrm{mg} / \mathrm{kg}, \mathrm{s.c}$. & & $\uparrow$ & 125 \\
\hline \multicolumn{5}{|l|}{ 5- $\mathrm{HT}_{3}$ agonist } \\
\hline 2-Me-5-HT & & $0.01-10 \mu \mathrm{M}$ & $\downarrow *$ & 127 \\
\hline
\end{tabular}

$\uparrow$ increase, $\vee$ decrease. ${ }^{*}: \mathrm{K}^{\dagger}(120 \mathrm{mM})$-evoked NA release. 
facilitatory effect in the rat striatum was mediated by 5 $\mathrm{HT}_{3}$ receptors. On the other hand, 8-OH-DPAT increased DA turnover (143) and firing activity of the majority of DA cells (144) in the VTA, suggesting that this facilitatory effect involved $5-\mathrm{HT}_{1 \mathrm{~A}}$ receptors. In contrast, Ennis et al. (145) reported that the addition of 5-HT decreased DA release from striatal slices. Electrical stimulation of DRN and MRN or local application of 5-HT into these areas produced inhibition of neuronal activity in the SN (146, 147). The firing rate of DA neurons in the VTA was reduced by the $5-\mathrm{HT}_{1 \mathrm{~B}}$ - and $5-\mathrm{HT}_{1 \mathrm{C}}$-receptor agonists, mCPP ( $m$-chlorophenylpiperazine) and TFMPP, whereas these were facilitated by the $5-\mathrm{HT}_{1 \mathrm{C}}$-receptor antagonist mesulergine, suggesting that 5-HT exerts an inhibitory action on DA neurons in the VTA through $5-\mathrm{HT}_{1 \mathrm{C}}$ receptors (144).

Microdialysis studies also showed either facilitation or inhibition of DA release; local administration of 5-HT (148) and the 5-HT-uptake inhibitor alaproclate (149) increased DA release from the rat striatum, indicating that both exogenous and endogenous 5-HT facilitate DA re- lease. Dialysate DA releases from the striatum (148) and cortex (150) were increased by 8-OH-DPAT. Furthermore, agonists for $5-\mathrm{HT}_{1 \mathrm{~B}}$ receptors $(148,149,151)$ and those for $5-\mathrm{HT}_{3}$ receptors (152) increased DA release. These results suggest that the facilitatory effect of DA release involved 5- $\mathrm{HT}_{1 \mathrm{~A}^{-}}, 5-\mathrm{HT}_{1 \mathrm{~B}^{-}}$and $5-\mathrm{HT}_{3}$ receptors. Recently, Bonhomme et al. (153) reported that the involvement of $5-\mathrm{HT}_{4}$ receptors, but not $5-\mathrm{HT}_{1^{-}}, 5-\mathrm{HT}_{2^{-}}$or $5-\mathrm{HT}_{3}$ receptors, in the facilitation of DA release from the rat striatum, in agreement with the results of an in vitro study (154). On the other hand, Dewey et al. (155) demonstrated with positron emission topography and microdialysis that 5-HT inhibited DA release from the striatum. Dialysate DA release from the NAC was also reduced by application of the 5-HT and 5-HT-uptake inhibitor citalopram $(155,156)$. Furthermore, $5-\mathrm{HT}_{2}$-receptor antagonists facilitated DA release, indicating that endogenous 5 -HT tonically inhibits DA release through $5-\mathrm{HT}_{2}$ receptors. Thus, the inhibitory effect of $5-\mathrm{HT}$ on $\mathrm{DA}$ release appeared may be mediated by $5-\mathrm{HT}_{2}$ receptors.

Table 8. Modulation of DA release by $5-\mathrm{HT}$ receptors from rat brain regions determined by in vivo microdialysis

\begin{tabular}{|c|c|c|c|c|c|c|}
\hline $\begin{array}{l}\text { 5-HT-receptor } \\
\text { agents }\end{array}$ & $\begin{array}{l}\text { Systemic } \\
\text { administration }\end{array}$ & $\begin{array}{l}\text { Local } \\
\text { administration }\end{array}$ & Striatum & Cortex & $\begin{array}{l}\text { Nucleus } \\
\text { accumbens }\end{array}$ & Ref. \\
\hline \multirow[t]{2}{*}{$5-\mathrm{HT}$} & & 0.1 and $0.4 \mu \mathrm{M}$ & & & $\uparrow$ & 156 \\
\hline & & $0.004-4 \mathrm{nmol}^{*}$ & $\wedge$ & & & 148 \\
\hline Citalopram & $20 \mathrm{mg} / \mathrm{kg}$, i.p. & & . & & & 155 \\
\hline Alaproclate & & $400 \mu \mathrm{M}$ & 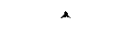 & & & 149 \\
\hline \multicolumn{7}{|l|}{$5-\mathrm{HT}_{1 \mathrm{~A}}$ agonist } \\
\hline \multirow[t]{2}{*}{ 8-OH-DPAT } & & $50 \mu \mathrm{M}$ & $\wedge$ & & & 148 \\
\hline & $25 \mu \mathrm{g} / \mathrm{kg}, \mathrm{s.c}$. & & $\rightarrow$ & $\uparrow$ & , & 150 \\
\hline \multicolumn{7}{|l|}{ 5-HT $1 \mathrm{~B}$ agonist } \\
\hline RU 24969 & & $50 \mu \mathrm{M}$ & * & & & 148 \\
\hline CGS 12066B & & $1 \mu \mathrm{M}$ & $\uparrow$ & & & 149 \\
\hline CP-93,129 & & $0.4-12 \mathrm{nmol}^{*}$ & $\uparrow$ & & & 151 \\
\hline mCPP & & $0.4-40 \mathrm{nmol}^{*}$ & $\uparrow$ & & & 148 \\
\hline TFMPP & & $10-160 \mathrm{nmol}^{*}$ & $\uparrow$ & & & 148 \\
\hline \multicolumn{7}{|l|}{ 5- $\mathrm{HT}_{2}$ agonist } \\
\hline \multirow[t]{3}{*}{ DOI } & & $12-120 \mathrm{nmol}^{*}$ & $\uparrow$ & & & 157 \\
\hline & & 1,10 and $100 \mathrm{ng}$ & & $\rightarrow$ & & 53 \\
\hline & $100 \mu \mathrm{g} / \mathrm{kg}$, i.v. & & & $\downarrow$ & & 53 \\
\hline \multicolumn{7}{|l|}{ 5- $\mathrm{HT}_{2}$ antagonist } \\
\hline Ritanserin & $0.63 \mathrm{mg} / \mathrm{kg}$, i.p. & & & & $\uparrow$ & 155 \\
\hline Altanserin & $20 \mathrm{mg} / \mathrm{kg}$, i.p. & & $\uparrow$ & & & 155 \\
\hline \multicolumn{7}{|l|}{ 5- $\mathrm{HT}_{3}$ agonist } \\
\hline 1-Phenylbiguanide & & $0.1-1 \mathrm{mM}$ & & & $\uparrow$ & 152 \\
\hline \multicolumn{7}{|l|}{ 5- $\mathrm{HT}_{4}$ agonist } \\
\hline BIMU 8 & & $100, \mu \mathrm{M}$ & $\uparrow$ & & & 153 \\
\hline
\end{tabular}

$\uparrow$ increase, $r$ decrease, $\rightarrow$ no effect. ${ }^{*}$ : perfusion during $20 \mathrm{~min}$ at flow rate $2 \mu \mathrm{l} / \mathrm{min}$. 


\section{IV-3. Acetylcholine release (Table 9)}

In vitro studies have shown that the serotonergic nervous system inhibits, rather than facilitates, the cholinergic neuronal activity in various brain regions $(158,159)$. However, the results of microdialysis studies suggested that 5-HT exerts various effects on $\mathrm{ACh}$ release in a brain-region-specific manner. For instance, 5-HT or the 5HT-uptake inhibitor fiuoxetine decreased $\mathrm{ACh}$ release from rat NAC (160). Systemic and local administration of 8-OH-DPAT decreased ACh release in NAC, suggesting that the inhibitory effect was mediated through $5-\mathrm{HT}_{1 \mathrm{~A}}$ receptors (160). On the other hand, dialysate $\mathrm{ACh}$ release from the hippocampus and cortex were also reduced by the $5-\mathrm{HT}_{1 \mathrm{~B}}$ agonists $(161,162)$, in agreement with in vitro results in both synaptosomes and slices $(163,164)$. Thus, both in vitro and in vivo findings indicate the presence of $5-\mathrm{HT}_{1 \mathrm{~B}}$ receptors not only on the serotonergic nerve terminals as homologous presynaptic autoreceptors, but also on the cholinergic nerve terminals as heteroreceptors. In contrast, hippocampal ACh release was increased by 5-HT-releasing agents $(165,166)$. Local administration of the 5-HT-uptake inhibitor citalopram also increased $A C h$ release (166), indicating that not only exogenous but also endogenous 5-HT had a facilitatory effect. ACh release was also increased by $8-\mathrm{OH}-$
DPAT, which effect was antagonized by the $5-\mathrm{HT}_{1 \mathrm{~A}}$ antagonist NAN-190 (1-(2-methoxyphenyl)-4-[4-(2-phthalimido)butyl]piperazine) (162). The authors speculated that serotonergic modulation of $\mathrm{ACh}$ release from the rat hippocampus is dependent on both the facilitation via 5 $\mathrm{HT}_{1 \mathrm{~A}}$ receptors and inhibition via $5-\mathrm{HT}_{1 \mathrm{~B}}$ receptors. Moreover, Consolo et al. (166) suggested that the facilitatory effect of $\mathrm{ACh}$ release is involved in $5-\mathrm{HT}_{3}$ receptors.

Bianchi et al. (167) showed, however, that i.c.v. injection of 2-Me-5-HT decreased dialysate ACh release from the cerebral cortex of guinea pigs, whereas systemic administration of 8-OH-DPAT increased ACh release. They speculated that 5-HT neurons have dual modulation; i.e. the stimulation of $5-\mathrm{HT}_{1 \mathrm{~A}}$ autoreceptors leads to disinhibition of the cholinergic cells that are tonically inhibited by serotonergic neurons, while the inhibitory effect mediated by $5-\mathrm{HT}_{3}$ receptors may be an indirect action through interneurons. In in vitro experiments using cortical slices of rats (158), guinea pigs (167) and human cortical synaptosomes (168), ACh release was inhibited by stimulation of $5-\mathrm{HT}_{3}$ receptors. With regards to the inhibitory effect by $5-\mathrm{HT}_{3}$ receptors in the rat entorhinal cortex, Johnson et al. (169) were critical of this data because they showed a lack of reproducibility. However, recent electrophysiological studies $(130,170)$ showed that

Table 9. Modulation of ACh release by 5-HT receptors from rat brain regions determined by in vivo microdialysis

\begin{tabular}{|c|c|c|c|c|c|c|}
\hline $\begin{array}{l}\text { 5-HT-receptor } \\
\text { agents }\end{array}$ & $\begin{array}{l}\text { Systemic } \\
\text { administration }\end{array}$ & $\begin{array}{l}\text { Local } \\
\text { administration }\end{array}$ & $\begin{array}{l}\text { Hippo- } \\
\text { campus }\end{array}$ & Cortex & $\begin{array}{l}\text { Nucleus } \\
\text { accumbens }\end{array}$ & Ref. \\
\hline \multirow[t]{3}{*}{$5-\mathrm{HT}$} & & 100 and $500 \mu \mathrm{M}$ & & & $\downarrow$ & 160 \\
\hline & & $10 \mu \mathrm{M}$ & $\rightarrow$ & & & 162 \\
\hline & & $1-5 \mathrm{mM}$ & a & & & 173 \\
\hline 5-MeO-DMT & & $1 \mathrm{mM}$ & $\hat{\vdots}$ & & & 173 \\
\hline$d$-Fenfluramine & $20 \mathrm{mg} / \mathrm{kg}$, i.p. & & $\uparrow$ & & & 166 \\
\hline p-Chloroamphetamine & & $2.5 \mathrm{mg} / \mathrm{kg}$, i.p. & $\uparrow$ & & & 165 \\
\hline Fluoxetine & & 0.2 and $1 \mathrm{mM}$ & & & $\psi$ & 160 \\
\hline Citalopram & & $10 \mu \mathrm{M}$ & $\uparrow$ & & & 166 \\
\hline Clomipramine & & $2 \mu \mathrm{M}$ & $\rightarrow$ & & & 162 \\
\hline \multicolumn{7}{|l|}{ 5-HT $\mathrm{HA}_{1 \mathrm{~A}}$ agonist } \\
\hline \multirow[t]{3}{*}{ 8-OH-DPAT } & $0.1-1 \mathrm{mg} / \mathrm{kg}$, s.c. & & & & $\downarrow$ & 160 \\
\hline & & 0.3 and $3 \mathrm{mM}$ & & & $\downarrow$ & 160 \\
\hline & & $20 \mu \mathrm{M}$ & $\uparrow$ & & & 162 \\
\hline \multicolumn{7}{|l|}{ 5-HT ${ }_{1 \mathrm{~B}}$ agonist } \\
\hline CGS 12066B & & $100 \mu \mathrm{M}$ & $\downarrow$ & & & 162 \\
\hline RU 24969 & $10 \mathrm{mg} / \mathrm{kg}$, i.p. & & & $\downarrow$ & & 161 \\
\hline \multicolumn{7}{|l|}{ 5- $\mathrm{HT}_{3}$ agonist } \\
\hline 2-Me-5-HT & & $250 \mu \mathrm{g}$, i.c.v. & $\uparrow$ & & & 166 \\
\hline \multicolumn{7}{|l|}{ 5- $\mathrm{HT}_{4}$ agonist } \\
\hline BIMU 1 & & $30-100 \mathrm{nmol}$, i.c.v. & $\rightarrow$ & $\uparrow$ & & 171 \\
\hline
\end{tabular}

$\uparrow$ increase, $\downarrow$ decrease, $\rightarrow$ no effect. 
microinontophoretically application of the $5-\mathrm{HT}_{3}$-receptor agonist produced suppression of cell firing in the rat medial prefrontal cortex.

Recently, it has been reported that $\mathrm{ACh}$ release from the rat frontal cortex was regulated by $5-\mathrm{HT}_{4}$ receptors; the 5- $\mathrm{HT}_{4}$-receptor agonists BIMU 1 (endo- $\mathrm{N}$-(8-methyl8-azabicyclo[3.2.1]oct-3-yl)-2,3-dihydro-3-ethyl-2-oxo$1 \mathrm{H}$-benzimidazole-1-carboxamide) and BIMU 8 (endo- $\mathrm{N}$ (8-methyl-8-azabicyclo [3.2.1] oct-3-yl)-2,3-dihydro-(1methyl)ethyl-2-oxo- $1 H$-benzimidazole- 1 -carboxamide) increased $\mathrm{ACh}$ release, and this was antagonized by a 5$\mathrm{HT}_{4}$-receptor antagonist (171). This modulation via 5$\mathrm{HT}_{4}$ receptors was not tonically activated because $5-\mathrm{HT}_{4}{ }^{-}$ receptor antagonists had no effect on $\mathrm{ACh}$ release. The facilitatory effect by $5-\mathrm{HT}_{4}$ receptors may be restricted to the cortex because 5- $\mathrm{HT}_{4}$ agonists did not affect $\mathrm{ACh}$ release from either the striatum or the hippocampus. 5$\mathrm{HT}_{2}$ receptors did not seem to contribute to the inhibitory effect in in vivo (167) and in vitro (164) despite the presence of $5-\mathrm{HT}_{2}$ receptors on cholinergic nerve terminals in the rat cortex (172).

\section{Possible role of serotonergic nervous systems in psy- chiatric disorders}

Medications that act on the central serotonergic nervous system have applications for the treatment of a variety of psychiatric disorders such as depression, anxiety, psychoses, eating disorders and obsessive compulsive disorder. A new generation of drugs acting on specific 5-HT receptors, carrier proteins and its degrative enzymes have not only the advantage of a low frequency of adverse effects but also usefulness as probes for the psychobiology of mental disorders. In this section, we will review and discuss evidence suggesting that the serotonergic nervous system plays a predominant role in emotional disorders and psychoses.

\section{V-1. Major depression (Tables 10 and 11)}

It is generally accepted that the readjustment of central serotonergic function is associated with the therapeutic properties of antidepressants. Typical antidepressant drugs such as 5-HT-uptake inhibitors and monoamine oxidase (MAO) inhibitors increase the synaptic availability of 5-HT by blocking its uptake and by inhibiting its degradation, respectively. However, two or three weeks are required before therapeutic improvement appears in depressed patients. This delayed onset of the clinical effect may be the result of subsensitivity of feedback regulation via somatodendritic 5-HT autoreceptors: Reduction of dialysate 5-HT levels in the rat DC elicited by the $5-\mathrm{HT}_{1 \mathrm{~A}}$ agonist 8-OH-DPAT was attenuated by chronic administration of fluoxetine (174), and inhibition of the firing rate of neurons in the raphe nucleus produced by activation of somatodendritic $5-\mathrm{HT}_{1 \mathrm{~A}}$ autoreceptors was attenuated by chronic administration of 5-HT-uptake inhibitors $(175,176)$. The desensitization of $5-\mathrm{HT}_{1 \mathrm{~A}}$ autoreceptors was caused by not only $5-\mathrm{HT}$ uptake inhibitors but also $5-\mathrm{HT}_{1 \mathrm{~A}}$ agonists $(177,178)$. Chronic treatment with 8-OH-DPAT attenuated this drug-induced reduction of dialysate 5-HT release from the rat striatum (179). Some studies, however, provided contrasting evidence that decreased 5 -HT release in the hippocampus by $5-\mathrm{HT}_{1 \mathrm{~A}}$ activation was not affected by

Table 10. Effects of chronic treatment with antidepressants on 5-HT release from rat brain regions determined by in vivo microdialysis

\begin{tabular}{|c|c|c|c|c|c|c|}
\hline \multirow{2}{*}{$\begin{array}{l}\text { Chronic treatment } \\
\text { of antidepressants }\end{array}$} & \multicolumn{2}{|c|}{ Autoreceptors } & \multirow{2}{*}{$\begin{array}{l}\text { Hetero- } \\
\text { receptor } \\
\quad \alpha_{2}\end{array}$} & \multicolumn{2}{|c|}{ Reduction of 5-HT release } & \multirow{2}{*}{ Ref. } \\
\hline & $5-\mathrm{HT}_{1 \mathrm{~A}}$ & $5-\mathrm{HT}_{1 \mathrm{~B}}$ & & region & acute treatment & \\
\hline \multicolumn{7}{|l|}{ 5- $\mathrm{HT}_{1 \mathrm{~A}}$ agonist } \\
\hline Buspirone $(2 \times 0.5 \mathrm{mg} / \mathrm{kg} /$ day $\times 14$, s.c. $)$ & $( \pm)$ & & & hippocampus & buspirone $(0.5 \mathrm{mg} / \mathrm{kg}, \mathrm{s} . \mathrm{c})$. & 180 \\
\hline Buspirone $(10 \mathrm{mg} / \mathrm{kg}$, b.i.d. $\times 10$ weeks $)$ & $( \pm)$ & & & hippocampus & buspirone $(0.5 \mathrm{mg} / \mathrm{kg}, \mathrm{s.c})$. & 181 \\
\hline Ipsapirone $(2 \times 5 \mathrm{mg} / \mathrm{kg} /$ day $\times 14$, s.c. $)$ & $( \pm)$ & & & hippocampus & ipsapirone $(0.5 \mathrm{mg} / \mathrm{kg}, \mathrm{s.c})$. & 180 \\
\hline 8-OH-DPAT $(2 \times 5 \mathrm{mg} / \mathrm{kg} /$ day $\times 14$, s.c. $)$ & $( \pm)$ & & & hippocampus or striatum & 8-OH-DPAT $(0.025 \mathrm{mg} / \mathrm{kg}$, s.c. $)$ & 180 \\
\hline 8-OH-DPAT $(1 \mathrm{mg} / \mathrm{kg} /$ day $\times 7, \mathrm{s.c})$. & $(-)$ & & & striatum & 8-OH-DPAT (1 mg/kg, s.c.) & 179 \\
\hline \multicolumn{7}{|l|}{ MAO inhibitor } \\
\hline MDL $72394(0.25 \mathrm{mg} / \mathrm{kg} /$ day $\times 21$, p.o. $)$ & & $( \pm)$ & & cortex & RU $24969(10 \mathrm{mg} / \mathrm{kg}$, i.p. $)$ & 193 \\
\hline \multicolumn{7}{|l|}{ 5-HT-uptake inhibitor } \\
\hline Amitriptyline $(10 \mathrm{mg} / \mathrm{kg} /$ day $\times 21, \mathrm{p} . \mathrm{o})$. & & $( \pm)$ & & cortex & RU 24969 (10 mg/kg, i.p.) & 193 \\
\hline Fluoxetine $(10 \mathrm{mg} / \mathrm{kg} /$ day $\times 14$, i.p. $)$ & $(-)$ & & & diencephalon & 8-OH-DPAT $(0.025 \mathrm{mg} / \mathrm{kg}, \mathrm{i} . \mathrm{v})$. & 174 \\
\hline \multicolumn{7}{|l|}{ NA-uptake inhibitor } \\
\hline Desipramine $(2 \times 10 \mathrm{mg} / \mathrm{kg} /$ day $\times 14$, i.p. $)$ & & & $(-)$ & hippocampus & UK $14,304(10 \mu \mathrm{M} \text { perfusion })^{*}$ & 201 \\
\hline
\end{tabular}

(-) desensitization, $( \pm)$ no effect. ${ }^{*}: \mathrm{K}^{+}(120 \mathrm{mM})$-evoked 5 -HT release. 
long-term treatment with $5-\mathrm{HT}_{1 \mathrm{~A}}$ agonists including 8OH-DPAT $(180,181)$. The question remains as to why the desensitization of $5-\mathrm{HT}_{1 \mathrm{~A}}$ autoreceptors was produced by chronic treatment with 5-HT-uptake inhibitors and also, unexpectedly, by $5-\mathrm{HT}_{1 \mathrm{~A}}$ agonists. The $5-\mathrm{HT}$ reuptake carrier exists not only in the nerve terminals but also in the cell bodies of 5-HT neurons (182). Several reports have furthermore shown that acute administration of 5HT-uptake inhibitors increases dialysate 5-HT levels to a greater extent in the raphe nucleus $(183-185)$. These results indicate that elevated extracellular 5-HT levels in the raphe nucleus produced by long-term administration of the 5-HT-uptake inhibitors may result in subsensitivity of $5-\mathrm{HT}_{1 \mathrm{~A}}$ autoreceptors.

Recently, Hjorth (186) reported that the enhancement of hippocampal 5-HT release by the 5-HT-uptake inhibitor citalopram was augmented by co-administration of 5- $\mathrm{HT}_{1 \mathrm{~A}}$-autoreceptor antagonists. Their study was based on the speculation that elevated 5-HT levels in the raphe nuclei activating $5-\mathrm{HT}_{1 \mathrm{~A}}$ autoreceptors inhibits subsequent 5-HT release. This finding led us to expect that a combination of 5-HT-uptake inhibitors and 5- $\mathrm{HT}_{1 \mathrm{~A}}$-autoreceptor blockers may be much more useful for inducing subsensitivity in 5- $\mathrm{HT}_{1 \mathrm{~A}}$ autoreceptors; such a combined regimen may be useful for the treatment of major depression. Indeed, a clinical study (187) demonstrated that the antidepressive efficacy of 5-HT-uptake inhibitors or MAO inhibitors was improved by coadministration of pindolol, a $\beta$-blocker with antagonistic properties at 5$\mathrm{HT}_{1 \mathrm{~A}}$ receptors (188); i.e., the onset of the antidepressive action was faster than the conventional therapy, and full antidepressive responses were observed in patients resistant to single treatment with 5-HT-uptake inhibitors or MAO inhibitors (187).

Several reports have shown that acute administration of either 5-HT-uptake inhibitors or MAO inhibitors increases dialysate 5-HT levels to a greater extent in the raphe nucleus than in the frontal cortex $(183,185,189)$. In addition, intra-raphe application of 5-HT-uptake inhibitor clomipramine decreased cortical 5-HT release (183). These results suggest that 5-HT-uptake inhibitors may be more effective on somatic reuptake carriers than on nerve terminals. The outcome of each site of action may be expected to be different.

Both in vitro experiments and electrophysiological studies have shown that terminal 5-HT autoreceptors $\left(5-\mathrm{HT}_{1 \mathrm{~B}^{-}}\right.$or $5-\mathrm{HT}_{1 \mathrm{D}}$ receptors) are subsensitized by longterm treatment with 5-HT-uptake inhibitors $(190,191)$. In addition, an in vitro study using rat hippocampal synaptosomes revealed that the chronic administration of citalopram produced desensitization of presynaptic 5$\mathrm{HT}_{1 \mathrm{~B}}$ heteroreceptors located on cholinergic nerve terminals (192). In contrast to these in vitro results, the reduction of $5-\mathrm{HT}$ release by the $5-\mathrm{HT}_{1 \mathrm{~B}}$ agonist RU 24969 measured by microdialysis was not altered by chronic administration of the 5-HT-uptake inhibitor or MAO inhibitor (193). Thus, the correlations between elevated synaptic 5-HT concentrations, changes in the sensitivity of 5$\mathrm{HT}_{1 \mathrm{~B}}$ receptors and psychiatric disorders are still unclear. Furthermore, subsensitivity of $5-\mathrm{HT}_{1 \mathrm{~B}}$ receptors was observed following repeated treatment with tianeptine, an antidepressant that enhances 5-HT uptake (194). It is

Table 11. Different responses of acute administration of antidepressants on 5-HT release from rat brain regions determined by in vivo microdialysis

\begin{tabular}{|c|c|c|c|c|c|}
\hline Antidepressant & $\begin{array}{l}\text { Systemic } \\
\text { administration }\end{array}$ & $\begin{array}{l}\text { Local } \\
\text { administration }\end{array}$ & $\begin{array}{l}\text { Dorsal } \\
\text { raphe }\end{array}$ & Cortex & Ref. \\
\hline \multicolumn{6}{|l|}{ 5-HT-uptake inhibitor } \\
\hline \multirow[t]{2}{*}{ Citalopram } & $1 \mathrm{mg} / \mathrm{kg}, \mathrm{i} . \mathrm{p}$ & & $\uparrow(\times 2$-fold $)$ & $\rightarrow$ & 185 \\
\hline & $10 \mathrm{mg} / \mathrm{kg}$, i.p. & & $\uparrow(\times 4$-fold $)$ & $\uparrow(\times 1.7$-fold $)$ & 185 \\
\hline Fluvoxamine & $10 \mathrm{mg} / \mathrm{kg}$, i.p. & & $\uparrow(\times 5.4-f o l d)$ & $\uparrow(\times 2.6$-fold $)$ & 184 \\
\hline \multirow[t]{4}{*}{ Clomipramine } & $20 \mathrm{mg} / \mathrm{kg}$, i.p. & & ( $(\times 2.9$-fold $)$ & 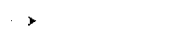 & 183 \\
\hline & & $40 \mu \mathrm{M}$ & & $\uparrow(\times 4.4-$ fold $)$ & 183 \\
\hline & & into raphe nucleus & & & \\
\hline & & $40 \mu \mathrm{M}$ & ${ }^{*}(\times 3.3$-fold $)$ & $\downarrow(-48 \%)$ & 183 \\
\hline \multicolumn{6}{|l|}{ MAO-A inhibitor } \\
\hline Clorgyline & $10 \mathrm{mg} / \mathrm{kg}$, i.p. & & $\uparrow(\times 4.5$-fold $)$ & $\rightarrow$ & 189 \\
\hline \multicolumn{6}{|l|}{ MAO-B inhibitor } \\
\hline Deprenyl & $2.5 \mathrm{mg} / \mathrm{kg}$, i.p. & & $\rightarrow$ & $\rightarrow$ & 189 \\
\hline \multicolumn{6}{|c|}{ Non-specific MAO inhibitor } \\
\hline Tranylcypromine & $15 \mathrm{mg} / \mathrm{kg}$, i.p. & & $\uparrow(\times 63$-fold $)$ & $\uparrow(\times 11$-fold $)$ & 189 \\
\hline
\end{tabular}

$\uparrow$ increase, $\downarrow$ decrease, $\rightarrow$ no effect. 
unlikely that this effect was due to down-regulation of $5-\mathrm{HT}_{1 \mathrm{~B}}$ receptors because no changes were observed in the density or affinity of $5-\mathrm{HT}_{1 \mathrm{~B}}$ sites on treatment with several antidepressants including tianeptine (195). Therefore, the desensitization of $5-\mathrm{HT}_{1 \mathrm{~B}}$ heteroreceptors might be mediated by a mechanism independent of synaptic 5HT availability, for instance, a molecular link between 5$\mathrm{HT}_{1 \mathrm{~B}}$ autoreceptors and the 5-HT transporter $(196,197)$. Taken together, these findings strongly suggest that changes in the synaptic concentration of 5-HT may not be responsible for induction of $5-\mathrm{HT}_{1 \mathrm{~B}}$-autoreceptor subsensitivity.

On the other hand, $\alpha_{2}$-heteroreceptors located on 5-HT nerve terminals were desensitized by long-term treatment with a MAO inhibitor (191) and a selective NA-uptake inhibitor (198). An $\alpha_{2}$-adrenoceptor antagonist such as $( \pm)$-mianserin and idazoxan, which have antidepressive effects (199), also caused desensitization of $\alpha_{2}$-heteroreceptors (200). Recently, we reported that the reduction of hippocampal dialysate 5 -HT release produced by the $\alpha_{2}$-adrenoceptor agonist UK 14,304 was attenuated by long-term administration of the NA-uptake inhibitor desipramine (201). These findings suggest that chronic administration of desipramine caused functional desensitization of $\alpha_{2}$-heteroreceptors located on 5-HT nerve terminals. We also found marked increases in dialysate NA concentrations in desipramine-treated rats. Thus, some antidepressants have the capacity to desensitize the $\alpha_{2}$-heteroreceptors on 5-HT nerve terminals by producing sustained increases in synaptic concentrations of NA. These observations support the hypothesis that the mechanism of action of antidepressant drugs involves an interaction between serotonergic and noradrenergic neuronal systems at the level of presynaptic heteroreceptors.

\section{V-2. Schizophrenia}

The 5-HT hypothesis of schizophrenia based on the hallucinogenic properties of lysergic acid diethylamide has been supported by neurochemical and binding studies $(202,203)$. Recent interest is focused on the possible role of 5-HT/DA interactions in the pathophysiology of schizophrenia. This is due to the findings that mixed 5$\mathrm{HT}_{2} / \mathrm{DA} \mathrm{D}_{2}$-antagonists are clinically useful antipsychotics. For instance, clozapine (204) and risperidone (205), atypical antipsychotics that have $5-\mathrm{HT}_{2}$-receptor antagonistic properties in addition to $\mathrm{DA} \mathrm{D}_{2}$-receptor blockade, were confirmed to be efficacious in treatmentresistant schizophrenia. Furthermore, attention has focused on the clinical evaluation of $5-\mathrm{HT}_{2}$-receptor antagonists as antipsychotic agents because with these drugs, there is only a low frequency of the extrapyramidal side effects that usually accompany the DA $\mathrm{D}_{2}$-receptor blockade produced by typical neuroleptics
$(206,207)$. This new strategy for antipsychotic therapy has emerged in place of conventional neuroleptics.

The ring-substituted amphetamine analog 3,4-methylenedioxymethamphetamine (MDMA) that produces both stimulant- and hallucinogen-like effects has proven to be a useful neurochemical tool for studying 5-HT/DA interactions. MDMA is a potent inducer of DA release and also has neurotoxic effects against 5-HT neurons (208-210). In vivo microdialysis experiments showed that MDMA increased the extracellular DA concentration in the rat striatum $(211,212)$ via a carrier-mediated (213) or impulse-mediated mechanism $(214,215)$. 5-HT ${ }_{2}$-receptor antagonists attenuated the activation of striatal DA release produced by MDMA (213-215), and the 5-HT agonist DOI augmented this response (216). The site of action whereby $5-\mathrm{HT}_{2}$ receptors modulate dopaminergic activity is unresolved. Local administration of amperozide by itself, however, increased DA release from the rat striatum $(217,218)$ and NAC $(218)$, suggesting that 5-HT can act directly within the terminal field to facilitate DA release through a $5-\mathrm{HT}_{2}$-receptor-mediated mechanism. These findings suggest that $5-\mathrm{HT}_{2}$ receptors enhance dopaminergic activity under conditions in which DA release is markedly enhanced. In addition, Svensson et al. (219) revealed that the selective $\mathrm{DA} \mathrm{D}_{2}$-antagonist raclopride-induced increase in DA concentration in the medial prefrontal cortex was enhanced by concurrent ritanserin administration. Thus, combined administration of $5-\mathrm{HT}_{2}$-receptor antagonists with low doses of a selective $\mathrm{DA}_{2}$-antagonist produces a more pronounced increase in DA output than either of these treatments alone in the areas of prefrontal dopaminergic projection. Similar preferential actions on DA transmission in the mesolimbocortical DA system have previously been reported with the atypical antipsychotic drug clozapine (220).

There are now some compounds with no DA $\mathrm{D}_{2}$-receptor blockade that appear to have antipsychotic activity without producing extrapyramidal side effects (221). Although there is no clear role for 5-HT in schizophrenia, the most compelling evidence at this time involves the antipsychotic efficacy of 5-HT/DA antagonists. Additional in vivo studies will be necessary to clarify the 5-HT system completely in schizophrenia.

\section{Conclusion}

In vivo microdialysis studies demonstrated that $5-\mathrm{HT}$ release from nerve terminals was functionally regulated through auto- and heteroreceptors. 5-HT release is also under the influence of some neuronal systems that act directly on raphe regions or indirectly via interneurons. Furthermore, 5-HT by itself plays an important role in 
modulation of the release of other neurotransmitters such as NA, DA and ACh via multiple 5-HT receptors. These results did not always agree with those obtained in vitro, and explanations proposed to date could not allow for some neuronal mechanisms. This might depend on different conditions; i.e., in addition to local-circuit neurons, many long projecting systems may remain and be intact in vivo. In this context, investigations using microdialysis methods have provided important information for elucidating the nature of the physiological interactions between 5-HT and other neuronal systems and furthermore, have contributed to evaluation of the pathophysiological significance of 5-HT neurons in psychiatric disorders. In fact, clinical trials based on the predictions obtained by in vivo microdialysis studies have revealed that combination therapy consisting of 5-HT-uptake inhibitors and $5-\mathrm{HT}_{1 \mathrm{~A}}$-autoreceptor antagonists ameliorated the therapeutic efficacy in depressive patients. A new therapeutic strategy for schizophrenia has also begun to emerge in terms of greater efficacy and fewer side effects by a new class of drug, 5-HT/DA antagonists. This concept was strongly supported by preclinical studies and in vivo microdialysis investigations. In the near future, microdialysis studies would not only contribute to elucidation of the physiological roles of serotonergic neuronal systems but also might be a powerful neurochemical approach for the design of clinically useful therapeutic strategies.

\section{REFERENCES}

1 Langer SZ: Presynaptic regulation of the release of catecholamines. Pharmacol Rev 32, 337-362 (1981)

2 Chesselet M-F: Presynaptic regulation of neurotransmitter release in the brain. Neuroscience 12, 347-375 (1984)

3 Starke K, Göthert $M$ and Kilbinger H: Modulation of neurotransmitter release by presynaptic autoreceptors. Physiol Rev 69, 864-989 (1989)

4 Göthert M and Schlicker E: Regulation of serotonin release in the central nervous systems by presynaptic heteroreceptors. In A Handbook, Edited by Feigerbaum J and Hanani M, Vol 2, pp 845-876, Freund, Tel Aviv (1991)

5 Ungerstedt $U$ and Hallström $\AA$; In vivo microdialysis-A new approach to the analysis of neurotransmitters in the brain. Life Sci 41, 861-864 (1987)

6 Benveniste $\mathrm{H}$ and Hüttemeier PC: Microdialysis-Theory and application. Prog Neurobiol 35, 195-215 (1990)

7 Gardner EL, Chen J and Paredes W: Overview of chemical sampling techniques. J Neurosci Methods 48, 173-197 (1993)

8 Yadid G, Pacak K, Kopin IJ and Goldstein AD: Modified microdialysis probe for sampling extracellular fluid and administering drugs in vivo. Am J Physiol 265, R1205-R1211 (1993)

9 Wages SA, Church WH and Justice JB Jr: Sampling considerations for on-line microbore liquid chromatography of brain dialysate. Anal Chem 58, 1649-1656 (1986)
10 Kreiss DS, Wieland S and Lucki l: The presence of a serotonin uptake inhibitor alters pharmacological manipulations of serotonin release. Neuroscience 52, 295-301 (1993)

11 Kalén P, Strecker RE, Rosengren E and Björkund A: Endogenous release of neuronal serotonin and 5 -hydroxyindoleacetic acid in the caudate-putamen of the rat as revealed by intracerebral dialysis coupled to high-performance liquid chromatography with fluorimetric detection. J Neurochem 51, 1422- 1434 (1988)

12 Griffiths R and Norman R: Effects of anaesthetics on uptake, synthesis and release of transmitters. Вг $\mathrm{J}$ Anaesth 71, 96-107 (1993)

13 Sharp T, Bramwell SR, Clark D and Grahame-Smith DG: In vivo measurement of extracellular 5-hydroxytryptamine in hippocampus of the anaesthetized rat using microdialysis: Changes in relation to 5-hydroxytryptaminergic neuronal activity. $\mathrm{J}$ Neurochem 53, 234-240 (1989)

14 Matos FF, Rollema $\mathrm{H}$ and Basbaum AI: Characterization of monoamine release in the lateral hypothalamus of awake, freely moving rats using in vivo microdialysis. Brain Res 528, 39-47 (1990)

15 Crespi F, Garratt JC, Sleight AJ and Marsden CA: In vivo evidence that 5-hydroxytryptamine (5-HT) neuronal firing and release are not necessarily correlated with 5-HT metabolism. Neuroscience 35, 139- 144 (1990)

16 Yoshioka M, Matsumoto M, Togashi H, Smith BC and Saito H: Effect of clonidine on the release of serotonin from the rat hippocampus as measured by microdialysis. Neurosci Lett 139, $57-60$ (1992)

17 Numazawa R, Yoshioka $M$, Matsumoto $M$, Togashi $H$, Kenmotsu $\mathrm{O}$ and Saito $\mathrm{H}$ : Pharmacological characterization of $\alpha_{2}$-adrenoceptor regulated serotonin release in the rat hippocampus. Neurosci Lett 192, 1-4 (1995)

18 Pazos A and Palacios JM: Quantitative autoradiographic mapping of serotonin receptors in the rat brain. I. Serotonin-1 receptors. Brain Res 346, 205-230 (1985)

19 De Montigny C, Blier P and Chaput Y: Electrophysiologicallyidentified serotonin receptors in the rat CNS. Effect of antidepressant treatment. Neuropharmacology 23, 1511-1520 (1984)

20 Sprouse JS and Aghajanian GK: (-)-Propranolol blocks the inhibition of serotonergic dorsal raphe cell firing by $5-\mathrm{HT}_{1 \mathrm{~A}}$ selective agonists. Eur J Pharmacol 128, 295-298 (1986)

21 Invernizzi $R$, Carli $M$, Di Clemente $A$ and Samanin $R$ : Administration of 8-hydroxy-2-(di-n-propylamino)tetralin in raphe nuclei dorsalis and medianus reduces serotonin synthesis in the rat brain: differences in potency and regional sensitivity. J Neurochem 56, 243-247 (1991)

22 Hutson PH, Sarna GS, O'Connell MT and Curzon G: Hippocampal 5-HT synthesis and release in vivo is decreased by infusion of 8-OHDPAT into the nucleus raphe dorsalis. Neurosci Lett 100, 276-280 (1989)

23 Sharp T, Bramwell RS and Grahame-Smith GD: 5-HT, agonists reduce 5-hydroxytryptamine release in rat hippocampus in vivo as determined by brain microdialysis. $\mathrm{Br} \mathrm{J}$ Pharmacol 96, 283-290 (1989)

24 Sharp, T, Bramwell RS, Hjorth S and Grahame-Smith GD: Pharmacological characterization of 8-OH-DPAT-induced inhibition of rat hippocampal 5-HT release in vivo as measured by microdialysis. Br J Pharmacol 98, 989-997 (1989) 
25 Bonvento G, Scatton B, Claustre Y and Rouquier L: Effect of local injection of 8-OH-DPAT into the dorsal or median raphe nuclei on extracellular levels of serotonin in serotonergic projection areas in the rat brain. Neurosci Lett 137, 101-104 (1992)

26 Kreiss DS and Lucki I: Differential regulation of serotonin (5$\mathrm{HT}$ ) release in the striatum and hippocampus by $5-\mathrm{HT}_{1 \mathrm{~A}}$ autoreceptors of the dorsal and median raphe nuclei. J Pharmacol Exp Ther 269, 1268 - 1278 (1994)

27 Kosofski BE and Molliver ME: The serotoninergic innervation of cerebral cortex: different classes of axon terminals arise from dorsal and median raphe nuclei. Synapse 1, 153-168 (1987)

28 Blier P, Serrano A and Scatton B: Differential responsiveness of the rat dorsal and median raphe 5 -HT systems to $5-\mathrm{HT}_{1}$ receptor agonists and $p$-chloroamphetamine. Synapse 5, 120-133 (1990)

29 Routledge C, Gurling J, Wright KI and Dourish TC: Neurochemical profile of the selective and silent $5-\mathrm{HT}_{\mathrm{IA}}$ receptor antagonist WAY100135: an in vivo microdialysis study. Eur J Pharmacol 239, 195-202 (1993)

30 Ferré S, Cortés $\mathbf{R}$ and Artigas F: Dopaminergic regulation of the serotonergic raphe-striatal pathway: Microdialysis studies in freely moving rats. J Neurosci 14, 4839-4846 (1994)

31 Adell A, Carceller A and Artigas F: In vivo brain dialysis study of the somatodendritic release of serotonin in the raphe nuclei of the rat: effects of 8-hydroxy-2-(di- $n$-propylamino)tetralin. J Neurochem 60, 1673-1681 (1993)

32 Bosker F, Klompmakers A and Westenberg H: Extracelluar 5hydroxytryptamine in median raphe nucleus of the conscious rat is decreased by nanomolar concentrations of 8-hydroxy-2(di- $n$-propylamino)tetralin and is sensitive to tetrodotoxin. $\mathrm{J}$ Neurochem 63, 2165-2171 (1994)

33 Middlemiss DN: The putative 5-HT 1 receptor agonist, RU 24969 , inhibits the efflux of 5-hydroxytryptamine from rat frontal cortex slices by stimulation of the 5-HT autoreceptor. J Pharm Pharmacol 37, 434-437 (1985)

34 Göthert M, Shlicker E, Fink K and Classen K: Effects of RU 24969 on serotonin release in rat brain cortex: further support for the identity of serotonin autoreceptors with $5-\mathrm{HT}_{1 \mathrm{~B}}$ sites. Arch Int Pharmacodyn Ther 288, 31-42 (1987)

35 Maura G, Roccatagliata E and Raiteri M: Serotonin autoreceptor in rat hippocampus: pharmacological characterization as a subtype of the 5- $\mathrm{HT}_{1}$ receptor. Naunyn Schmiedebergs Arch Pharmacol 334, 323-326 (1986)

36 Bonanno G, Maura G and Raiteri M: Pharmacological characterization of release-regulating serotonin autoreceptors in rat cerebellum. Eur J Pharmacol 126, 317-321 (1986)

37 Brazell MP, Marsden CA, Nisbet AP and Routledge C: The 5$\mathrm{HT}_{1}$ receptor agonist RU-24969 decreases 5-hydroxytryptamine (5-HT) release and metabolism in the rat frontal cortex in vitro and in vivo. Br J Pharmacol 86, 209-216 (1985)

38 Martin KF, Hannon S, Phillips I and Heal DJ: Opposing roles for $5-\mathrm{HT}_{1 \mathrm{~B}}$ and $5-\mathrm{HT}_{3}$ receptors in the control of 5-HT release in rat hippocampus in vivo. Br J Pharmacol 106, 139-142 (1992)

39 Schoeffter $\mathbf{P}$ and Hoyer $\mathrm{D}$ : Interaction of arylpiperazines with 5-HT $1 \mathrm{~A}, 5-\mathrm{HT}_{1 \mathrm{~B}}, 5-\mathrm{HT}_{1 \mathrm{C}}$, and 5-HT $\mathrm{HD}_{\mathrm{LD}}$ receptors: do discriminatory $5-\mathrm{HT}_{\mathrm{IB}}$ receptor ligands exist? Naunyn Schmiedebergs Arch Pharmacol 339, 675-683 (1989)

40 Auerbach SB, Ruitter JJ and Juliano PJ: Substituted piperazine and indole compounds increase extracellular serotonin in rat diencephalon as determined by in vivo microdialysis. Neuropharmacology 30, 307-311 (1991)

41 Pettibone DJ and Williams M: Serotonin-releasing effects of substituted piperazines in vitro. Biochem Pharmacol 33, 1531 - 1535 (1984)

42 Auerbach SB, Kamalakannan N and Rutter J: TFMPP and RU24969 enhance serotonin release from rat hippocampus. Eur J Pharmacol 190, $51-57$ (1990)

43 Fuller RW, Snoddy HD, Mason NR, Hemrick-Luecke SK and Clemens JA: Substituted piperazines as central serotonin agonists: comparative specificity of the postsynaptic actions of quipazine and $m$-trifluoromethylphenyl-piperazine. J Pharmacol Exp Ther 218, 636-641 (1981)

44 Hjorth S and Tao R: The putative 5-HT 18 receptor agonist CP93,129 suppresses rat hippocampal 5-HT release in vivo: comparison with RU 24969. Eur J Pharmacol 209, 249-252 (1991)

45 Lawrence AJ and Marsden CA: Terminal autoreceptor control of 5-hydroxytryptamine release as measured by in vivo microdialysis in the conscious guinea pig. J. Neurochem 58 , $142-146$ (1992)

46 Hoyer D and Middlemiss DN: Species differences in the pharmacology of terminal 5-HT autoreceptors in mammalian brain. Trends Pharmacol Sci 10, 130-132 (1989)

47 Schoffeter P and Hoyer D: 5-Hydroxytryptamine 5-HT $\mathrm{H}_{1 \mathrm{~B}}$ and 5$\mathrm{HT}_{1 \mathrm{D}}$ receptors mediating inhibition of adenylate cyclase activity. Pharmacological comparison with special reference to the effects of yohimbine, rauwolscine and some $\beta$-adrenoceptor antagonists. Naunyn Schmiedebergs Arch Pharmacol 340, 285-292 (1989)

48 Starkey SJ and Skingle $\mathrm{M}: 5-\mathrm{HT}_{1 \mathrm{D}}$ as well as $5-\mathrm{HT}_{1 \mathrm{~A}}$ autoreceptors modulate $5-\mathrm{HT}$ release in the guinea pig dorsal raphe nucleus. Neuropharmacology 33, 393-402 (1994)

49 Hamblin MW and Metcalf MA: Primary structure and functional characterization of a human $5-\mathrm{HT}_{1 \mathrm{D}}$-type serotonin receptor. Mol Pharmacol 40, 143-148 (1991)

50 Jin H, Oksenberg D, Askenazi A, Peroutka SJ, Duncan AM, Rozmahel R, Yang Y, Mengod G, Palacios JM and O'Dowd BF: Characterization of the human 5-hydroxytryptamine ${ }_{1 B}$ receptor. J Biol Chem 267, 5735- 5738 (1992)

51 Peroutka SJ: 5-Hydroxytryptamine receptors. J Neurochem 60, 408-416 (1993)

52 Hoyer D, Clarke DE, Fozard JR, Harting PR, Martin GR, Mylecharane EJ, Saxena PR and Humphrey PPA: International Union of Pharmacology classification of receptors for 5-hydroxytryptamine (serotonin). Pharmacol Rev 46, 157-203 (1994)

53 Garratt JC and Marsden CA: Effects of the 5- $\mathrm{HT}_{2}$ agonist DOI on DRN 5-HT neuronal firing and intake of food in freely feeding rats. Br J Pharmacol 98, 638P (1989)

54 Wright IK, Garratt JC and Marsden CA: Effects of a selective 5$\mathrm{HT}_{2}$ agonist, DOI, on 5-HT neuronal firing in the dorsal raphe nucleus and 5-HT release and metabolism in the frontal cortex. Br J Pharmacol 99, 221-222 (1990)

55 Garratt JC, Kidd EJ, Wright IK and Marsden CA: Inhibition of 5-hydroxytryptamine neuronal activity by the 5-HT agonist, DOI. Eur J Pharmacol 199, 349-355 (1991)

56 Williams GM, Smith DL and Smith DJ: $5-\mathrm{HT}_{3}$ receptors are not involved in the modulation of the $\mathrm{K}^{+}$-evoked release of $\left[{ }^{3} \mathrm{H}\right] 5$ HT from spinal cord synaptosomes of rat. Neuropharma- 
cology 31, 725-733 (1992)

57 Blier P, Monroe PJ, Bouchard C, Smith DL and Smith DJ: 5$\mathrm{HT}_{3}$ receptors which modulate $\left[{ }^{3} \mathrm{H}\right] 5-\mathrm{HT}$ release in the guinea pig hypothalamus are not autoreceptors. Synapse 15, 143-148 (1993)

58 Blier $\mathrm{P}$ and Bouchard C: Functional characterization of a 5$\mathrm{HT}_{3}$ receptor which modulates the release of 5 -HT in the guinea pig brain. Br J Pharmacol 108, 13-22 (1993)

59 Galzin AM, Poncet $\mathrm{V}$ and Langer SZ: $5-\mathrm{HT}_{3}$ receptor agonists enhance the electrically-evoked release of $\left[{ }^{3} \mathrm{H}\right] 5-\mathrm{HT}$ in guinea pig frontal cortex slices. Br J Pharmacol 100, 307P (1990)

60 Meltzer HY, Matsubara S and Lee J-C: Classification of typical and atypical antipsychotic drugs on the basis of dopamine D-1, D-2 and serotonin ${ }_{2} \mathrm{pK}_{\mathrm{i}}$ values. J Pharmacol Exp Ther 251, 238-246 (1989)

61 Ceulemans DLS, Hoppenbrouwers M, Gelders YG and Reyntjens AJM: The influence of ritanserin, a serotonin antagonist, in anxiety disorders: A double-blind placebo-controlled study versus Iorazepam. Pharmacopsychiatry 18, $303-305$ (1985)

62 Jones BJ, Costall B, Domeney AM, Kelly ME, Naylor RJ, Oakley NR and Tyers MB: The potential anxiolytic activity of GR 38032F, a 5-HT 3 receptor antagonist. Br J Pharmacol 93, $985-993$ (1988)

63 Yoshioka M, Matsumoto M, Togashi $\mathrm{H}$ and Saito $\mathrm{H}$ : Effects of conditioned fear stress on 5-HT release in the rat prefrontal cortex. Pharmacol Biochem Behav 51, 515-519 (1995)

64 Maura G, Gemignani A and Raiteri M: Noradrenaline inhibits central serotonin release throught alpha $a_{2}$-adrenoceptors located on serotonergic nerve terminals. Naunyn Schmiedebergs Arch Pharmacol 320, 272-274 (1982)

65 Maura $G$, Bonanno $G$ and Raiteri M: Presynaptic $\alpha_{2}-$ adrenoceptors mediating inhibition of noradrenaline and 5hydroxytryptamine release in rat cerebral cortex: further characterization as different $\alpha_{2}$-adrenoceptor subtypes. Naunyn Schmiedebergs Arch Pharmacol 345, 410-416 (1992)

66 Trendelenburg A-U, Trendelenburg M, Starke $\mathrm{K}$ and Limberger $\mathrm{N}$ : Release-inhibiting $\alpha_{2}$-adrenoceptors at serotonergic axons in rat and rabbit brain cortex: evidence for pharmacological identity with $\alpha_{2}$-autoreceptors. Naunyn Schmiedebergs Arch Pharmacol 349, 25-33 (1994)

67 Limberger N, Bonanno G, Späth L and Starke K: Autoreceptors and $w_{2}$-adrenoceptors at the serotonergic axons of rabbit brain cortex. Naunyn Schmiedebergs Arch Pharmacol 332, $324-331$ (1986)

68 Raiteri M, Maura G, Folghera S, Cavazzani P, Andrioli GC, Schlicker E, Schalnus R and Göthert $M$ : Modulation of 5hydroxytryptamine release by presynaptic inhibitory $\alpha_{2^{-}}$ adrenoceptors in the human cerebral cortex. Naunyn Schmiedebergs Arch Pharmacol 342, 508-512 (1990)

69 Tao R and Hjorth S: $\alpha_{2}$-Adrenoceptor modulation of rat ventral hippocampal 5-hydroxytryptamine release in vivo. Naunyn Schmiedebergs Arch Pharmacol 345, 137-143 (1992)

70 Frankhuijzen AL, Wardeh G, Hogenboom $\mathrm{F}$ and Mulder AH: $\alpha_{2}$-Adrenoceptor mediated inhibition of the release of radiolabelled 5-hydroxytryptamine and noradrenaline from slices of the dorsal region of the rat brain. Naunyn Schmiedebergs Arch Pharmacol 337, 255-260 (1988)

71 Baraban JM and Aghajanian GK: Suppression of firing activity of 5-HT neurons in the dorsal raphe by alpha-adrenoceptor antagonists. Neuropharmacology 19, 355-363 (1980)

72 Pei Q, Zetterström $\mathrm{T}$ and Fillenz M: Effects of noradrenergic and cholinergic drugs on 5-HT release in hippocampus measured by microdialysis. Eur J Pharmacol 183, 1919P (1990)

73 Feuerstein TJ, Mutschler A, Lupp A, Van Velthoven V, Schlicker E and Göthert M: Endogenous noradrenaline activates $\alpha_{2}$-adrenoceptors on serotonergic nerve endings in human and rat neocortex. J Neurochem 61, 474-480 (1993)

74 Feuerstein TJ, Hertting $G$ and Jackisch R: Endogenous noradrenaline as modulator of hippocampal serotonin (5-HT)release. Naunyn Schmiedebergs Arch Pharmacol 329, 216-221 (1985)

75 Galzin AM, Moret C and Langer SZ: Evidence that exogenous but not endogenous noradrenaline activates the presynaptic alpha $_{2}$ adrenoceptors on serotonergic nerve endings in the rat hypothalamus. J Pharmacol Exp Ther 228, 725-732 (1984)

76 Limberger N, Bonanno G, Späth L and Starke K: Autoreceptors and $\alpha_{2}$-adrenoceptors at the serotonergic axons of rabbit brain cortex. Naunyn Schmiedebergs Arch Pharmacol 332, 324-331 (1986)

77 Blier P, Ramdine R, Galzin AM and Langer SZ: Frequencydependence of serotonin but not $\alpha_{2}$-adrenergic inhibition of $\left[{ }^{3} \mathrm{H}\right]-5-\mathrm{HT}$ release in rat hypothalamic slices. Naunyn Schmiedebergs Arch Pharmacol 339, 60-64 (1989)

78 Mongeau $\mathrm{R}$, Blier $\mathrm{P}$ and de Montigny $\mathrm{C}$ : In vivo electrophysiological evidence for tonic activation by endogenous noradrenaline of $\alpha_{z}$-adrenoceptors on 5-hydroxytryptamine terminals in the rat hippocampus. Naunyn Schmiedebergs Arch Pharmacol 347, 266-272 (1993)

79 Cheng CHK, Costall B, Ge J and Naylor RJ: The profiles of interaction of yohimbine with anxiolytic and putative anxiolytic agents to modify 5-HT release in the frontal cortex of freelymoving rats. Br J Pharmacol 110, 1079-1084 (1993)

80 De Boer T, Nefkens F and Van Helvoirt A: The $\alpha_{2}$-adrenoceptor antagonist Org 3770 enhances serotonin transmission in vivo. Eur J Pharmacol 253, R5-R6 (1994)

81 Mackinnon AC, Spedding $\mathrm{M}$ and Brown CM: $\alpha_{2}$-Adrenoceptors: more subtypes but fewer functional differences. Trends Pharmacol Sci 15, 119-123 (1994)

82 Raiteri M, Maura G and Versace P: Functional evidence for two stereochemically different alpha-2 adrenoceptors regulating central norepinephrine and serotonin release. J Pharmacol Exp Ther 224, 679-684 (1983)

83 Maura G, Gemignani A and Raiteri M: $\alpha_{2}$-Adrenoceptors in rat hypothalamus and cerebral cortex: Functional evidence for pharmacologically distinct subpopulations. Eur J Pharmacol 116, 335-339 (1985)

84 Messing RB and Lytle LD: Serotonin-containing neurons: Their possible role in pain and analgesia. Pain 4, 1-21 (1977)

85 Yarbrough GG, Buxbaum, DM and Sanders-Bush E: Biogenic amines and narcotic effect. II. Serotonin turnover in the rat after acute and chronic morphine administration. J Pharmacol Exp Ther 185, 328-335 (1973)

86 Grauer SM, Tao R and Auerbach SB: Morphine induces an increase in extracellular serotonin in the rat diencephalon. Brain Res 599, 277-282 (1992)

87 Tao R and Auerbach SB: Increased extracellular serotonin in rat brain after systemic or intraraphe administration of morphine. J Neurochem 63, 517-524 (1994)

88 Way EL, Loh HH and Shen FH: Morphine tolerance, physical 
dependence and synthesis of brain 5-hydroxytryptamine. Science 162, 1290-1292 (1968)

89 Godefroy, F, Weil-Fugazza J, Coudert D and Besson JM: Effect of acute administration of morphine on newly synthesized 5-hydroxytryptamine in spinal cord of the rat. Brain Res $199,415-424$ (1980)

90 Boadle-Biber MC, Johannessen JN, Narasimhachari $\mathrm{N}$ and Phan T-H: Activation of cortical tryptophan hydroxylase by acute morphine treatment: blockade by 6-hydroxydopamine. Eur J Pharmacol 139, 193-204 (1987)

91 Matos FF, Rollema H, Brown JL and Basbaum AI: Do opioids evoke the release of serotonin in the spinal cord? An in vivo microdialysis study of the regulation of extracellular serotonin in the rat. Pain 48, 439-447 (1992)

92 Monroe PJ, Michaux K and Smith DF: Evaluation of the direct actions of drugs with a serotoninergic link in spinal analgesia on the release of $\left[{ }^{3} \mathrm{H}\right]$ serotonin from spinal cord synaptosomes. Neuropharmacology 25, 261-265 (1986)

93 Parenti M, Tirone F, Olgialti VR and Groppetti A: Presence of opiate receptors on striatal serotoninergic nerve terminals. Brain Res 280, 317-322 (1983)

94 Passarelli $\mathrm{F}$ and Costa $\mathrm{T}$ : $\mathrm{Mu}$ and delta opioid receptors inhibit serotonin release in rat hippocampus. J Pharmacol Exp Ther 248, 299-305 (1989)

95 Yoshioka M, Matsumoto M, Togashi H, Smith, CB and Saito $\mathrm{H}$ : Opioid receptor regulation of 5-hydroxytryptamine release from the rat hippocampus measured by in vivo microdialysis. Brain Res 613, 74-79 (1993)

96 Mulder AH, Wardeh G, Hogenboom F and Frankhuyzen AL: $\kappa$ - and $\delta$-Opioid receptor agonists differentially inhibit striatal dopamine and acetylcholine release. Nature 308, 278-280 (1984)

97 Werling LL, Frattali A, Portoghese PS, Takemori AE and Cox BM: Kappa-receptor regulation of dopamine release from striatum and cortex of rats and guinea pigs. J Pharmacol Exp Ther 246, 282-286 (1988)

98 Mulder AH, Burger DM, Wardeh G, Hogenboom F and Frankhuyzen AL: Pharmacological profile of various $\kappa$-agonists at $\kappa^{-}, \mu$-and $\delta$-opioid receptors mediating presynaptic inhibition of neurotransmitter release in the rat brain. $\mathrm{Br} \mathrm{J}$ Pharmacol 102, 518-522 (1991)

99 Mulder AH, Hogenboom F, Warden G and Schoffelmeer ANM: Morphine and enkephalins potently inhibit $\left[{ }^{3} \mathrm{H}\right]-\mathrm{NA}$ release from rat brain cortex synaptosomes: Further evidence for a presynaptic localization of mu opioid receptors $J$ Neurochem 48, 1043 - 1047 (1987)

100 Matsumoto $M$, Yoshioka $M$, Togashi $H$, Hirokami $M$, Tochihara M, Ikeda T, Smith CB and Saito H: Mu-opioid receptors modulate noradrenaline release from the rat hippocampus as measured by brain microdialysis. Brain Res 636, $1-8$ (1994)

101 Haigler HJ: Morphine: effects on serotonergic neurons and neurons in areas with a serotonergic input. J Pharmacol 51, $361-376$ (1978)

102 Klitenick MA, DeWitte P and Kalivas PW: Regulation of somatodendritic dopamine release in ventral tegmental area by opioids and GABA: an in vivo microdialysis study. J Neurosci 12, 2623-2632 (1992)

103 Zieglgänsberger W, French ED, Siggins GR and Bloom FE: Opioid peptides may excite hippocampal pyramidal neurons by inhibiting adjacent inhibitory interncurons. Science 205 , 415-417 (1979)

104 Van der Kooy D and Hattori T: Dorsal raphe cells with collateral projections to the caudate-putamen and substantia nigra: a fluorescent retrograde double labelling study in the rat. Brain Res 186, 1 - 7 (1980)

105 Herve DH, Pickel VM, Joh TH and Beaudet A: Serotonin axon terminals in the ventral tegmental area of the rat: fine structure and synaptic input to dopaminergic neurons. Brain Res $\mathbf{4 3 5}$, $71-83$ (1987)

106 Lee EHY and Geyer MA: Indirect effects of apomorphine on serotoninergic neurons in rats. Neuroscience 11, 437-442 (1984)

107 Lee EHY: Additive effects of apomorphine and clonidine on serotonin neurons in the dorsal raphe. Life Sci 40, 635-642 (1987)

108 Sloviter RS, Drust EG and Connor JD: Evidence that serotonin mediates some behavioural effects of amphetamine. J Pharmacol Exp Ther 206, 348-352 (1978)

109 Copeland RL, Aulakh CS, Bhattacharyya AK and Pradhan SN: Behavioural depression and its neurochemical correlates at high doses of $d$-amphetamine in rats. Neuropharmacology 19 , $1027-1030$ (1980)

110 Reubi JC, Emson PC, Jessell TM and Iversen LL: Effects of GABA, dopamine, and substance $P$ on the release of newly synthesized ${ }^{3} \mathrm{H}-5$-hydroxytryptamine from rat substantia nigra in vitro. Naunyn Schmiedebergs Arch Pharmacol 304, 271-275 (1978)

111 Kelly E, Jenner $P$ and Marsden CD: The effects of dopamine and dopamine agonists on the release of ${ }^{3} \mathrm{H}-\mathrm{GABA}$ and ${ }^{3} \mathrm{H}-5 \mathrm{HT}$ from rat nigral slices. Biochem Pharmacol 34, 2655-2662 (1985)

112 Balfour DJK and Clasper P: Evidence for a presynaptic dopamine receptor in rat hippocampus. $\mathrm{Br} \mathrm{J}$ Pharmacol 76, 292P (1982)

113 Balfour DJK and Iyaniwura TT: An investigation of amphetamine-induced release of 5-HT from rat hippocampal slices. Eur J Pharmacol 109, 395-399 (1985)

114 Sokoloff P, Giros B, Martes MP, Bouthenet ML and Schwartz $\mathrm{JC}$ : Molecular cloning and characterization of a novel dopamine receptor $\left(D_{3}\right)$ as a target for neuroleptics. Nature 347, 146- 151 (1990)

115 Kebabian JB and Calne DB: Multiple receptors for dopamine. Nature 277, 93-96 (1979)

116 Galzin AM, Dubocovich ML and Langer SZ: Presynaptic inhibition by dopamine receptor agonists of noradrenergic neurotransmission in the rabbit hypothalamus. J Pharmacol Exp Ther 221, 461-471 (1982)

117 Baud P, Arbilla S and Langer SZ: Inhibition of the electrically evoked release of $\left[{ }^{3} \mathrm{H}\right]$ acetylcholine in rat striatal slices: an experimental model for drugs that enhance dopaminergic neurotransmission. J Neurochem 44, 331 - 337 (1985)

118 Arbilla S and Langer SZ: Stereoselectivity of presynaptic autoreceptors modulating dopamine release. Eur J Pharmacol 76, 345-351 (1981)

119 Benkirane S, Arbilla S and Langer SZ: A functional response to $D_{1}$ dopamine receptor stimulation in the central nervous system: inhibition of the release of $\left[{ }^{3} \mathrm{H}\right]$-serotonin from the rat substantia nigra. Naunyn Schmiedebergs Arch Pharmacol 335, 502-507 (1987) 
120 Bouthenet ML, Martres MP, Sales N and Schwartz JC: A detailed mapping of dopamine D-2 receptors in rat central nervous system by autoradiography with $\left[{ }^{125} \mathrm{I}\right]$ iodosulpiride. Neuroscience 20, 117-155 (1987)

121 Ferré $S$ and Artigas $F$ : Dopamine $\mathrm{D}_{2}$ receptor-mediated regulation of serotonin extracellular concentration in the dorsal raphe nucleus of freely moving rats. J Neurochem 61, 772-775 (1993)

122 Renaud B, Buda M, Lewis D and Pujol JF: Effect of 5,6-dihydroxytryptamine on tyrosine hydroxylase activity in central catecholamine neurons of the rat. Biochem Pharmacol 24, $1739-1742$ (1975)

123 McRae-Degueurce A, Dennis T, Leger L and Scatton B: Regulation of noradrenergic neuronal activity in the rat locus coeruleus by serotonergic afferents. Physiol Psychol 13, $188-196$ (1985)

124 Done CJG and Sharp T: Evidence that $5-\mathrm{HT}_{2}$ receptor activation decreases noradrenaline release in rat hippocampus in vivo. Br J Pharmacol 107, 240-245 (1992)

125 Done CJG and Sharp T: Biochemical evidence for the regulation of central noradrenergic activity by $5-\mathrm{HT}_{1 \mathrm{~A}}$ and $5-\mathrm{HT}_{2}$ receptors: microdialysis studies in the awake and anaesthetized rat. Neuropharmacology 33, 411-421 (1994)

126 Gorea $\mathrm{E}$ and Adrien J: Serotonergic regulation of noradrenergic coerulean neurons: Electrophysiological evidence for the involvement of 5- $\mathrm{HT}_{2}$ receptors. Eur J Pharmacol 154, 285-291 (1988)

127 Matsumoto M, Yoshioka M, Togashi H, Tochihara M, Ikeda T and Saito $\mathrm{H}$ : Modulation of norepinephrine release by serotonergic receptors in the rat hippocampus as measured by in vivo microdialysis. J Pharmacol Exp Ther 272, 1044-1051 (1995)

128 Blandina P, Goldfarb J, Walcott J and Green JP: Serotonergic modulation of the release of endogenous norepinephrine from rat hypothalamic slices. J Pharmacol Exp Ther 256, 341-347 (1991)

129 Goldfarb J, Walcott $\mathbf{J}$ and Blandina P: Serotonergic modulation of L-glutamic acid-evoked release of endogenous norepinephrine from rat hypothalamus. J Pharmacol Exp Ther 267, 45-50 (1993)

130 Ashby CA, Edwards E, Harkins KL and Wang RY: Differentia] effect of typical and atypical antipsychotic drugs on the suppressant action of 2-methyl serotonin on medial prefrontal cortical cells: A microiontophoretic study. Eur J Pharmacol 166, 583-584 (1989)

131 Edwards E, Harkins K, Ashby CR $\mathrm{J}_{\mathrm{r}}$ and Wang RY: Effect of 5-hydroxytryptamine ${ }_{3}$ receptor agonists on phosphoinositide hydrolysis in the rat frontocingulate and entorhinal cortices. $\mathbf{J}$ Pharmacol Exp Ther 256, 1025-1032 (1991)

132 Bowery NG, Hill DR, Hudson AL, Doble A, Middlemiss DN, Shaw $J$ and Turnbull M: (-)Baclofen decreases neurotransmitter release in the mammalian CNS by an action at a novel GABA receptor. Nature 283, $92-94$ (1980)

133 Misu Y, Goshima Y, Ueda H and Kubo T: Presynaptic inhibitory dopamine receptors on noradrenergic nerve terminals: Analysis of biphasic actions of dopamine and apomorphine on the release of endogenous norepinephrine in rat hypothalamic slices. J Pharmacol Exp Ther 235, 771-777 (1985)

134 Hamon M, Fattacini CM, Adrien J, Gallisot MC, Martin P and Gozlan $H$ : Alterations of central serotonin and dopamine turnover in rats treated with ipsapirone and other 5-hydroxy- tryptamine $_{\mathrm{AA}}$ agonists with potential anxiolytic properties. J Pharmacol Exp Ther 246, 745-752 (1988)

135 Sanghera MK, Coke JA, Williams HL and McMillen BA: Ipsapirone and 1-(2-pyrimidinyl)-piperazine increase rat locus coeruleus noradrenergic activity. Brain Res Bull 24, 17-22 (1990)

136 Piercey MF, Smith MW and Lum-Ragan JT: Excitation of noradrenergic cell firing by 5-hydroxytryptamine ${ }_{1 \mathrm{~A}}$ agonists correlates with dopamine antagonist properties. J Pharmacol Exp Ther 268, 1297-1303 (1994)

137 Mongeau R, De Montigny $\mathrm{C}$ and Blier P: Activation of 5- $\mathrm{HT}_{3}$ receptors enhances the electrically evoked release of $\left[{ }^{3} \mathbf{H}\right]-$ noradrenaline in rat brain limbic structures. Eur $\mathbf{J}$ Pharmacol 256, $269-279$ (1994)

138 Kidd EJ, Laporte AM, Langlois X, Fattaccini C-M, Doyen C, Lombard MC, Gozlan $\mathrm{H}$ and Hamon M: 5-HT $\mathrm{H}_{3}$ receptors in the rat central nervous system are mainly located on nerve fibres and terminals. Brain Res 612, 289-298 (1993)

139 Schlicker F, Kathmann M, Exner HJ, Detzner M and Göthert $\mathrm{M}$ : The $5-\mathrm{HT}_{3}$ receptor agonist 1 -( $m$-chlorophenyl)-biguanide facilitates noradrenaline release by blockade of $\alpha_{2}$-adrenoceptors in the mouse brain cortex. Naunyn Schmiedebergs Arch Pharmacol 349, 20-24 (1994)

140 Nedegaard S, Bolam JP and Greenfield SA: Facilitation of a dendritic calcium conductance by 5 -hydroxytryptamine in the substantia nigra. Nature 333, 174-177 (1988)

141 Williams J and Davies JA: The involvement of 5-hydroxytryptamine in the release of dendritic dopamine from slices of rat substantia nigra. J Pharm Pharmacol 35, 734-737 (1983)

142 Blandina P, Goldfarb J, Craddock-Royal B and Green JP: Release of endogenous dopamine by stimulation of 5-hydroxytryptamine $_{3}$ receptors in rat striatum. J Pharmacol Exp Ther 251, 803-809 (1989)

143 Ahlenius S, Hillegaart $V$ and Wijkström A: Increased dopamine turnover in the ventral striatum by 8-OH-DPAT administration in the rat. J Pharm Pharmacol 42, 285-288 (1990)

144 Prisco S, Pagannone S and Esposito E: Serotonin-dopamine interaction in the rat ventral tegmental area: an electrophysiological study in vivo. J Pharmacol Exp Ther 271, 83-90 (1994)

145 Ennis C, Kemp JD and Barry C: Characterization of inhibitory 5-hydroxytryptamine receptors that modulate dopamine release in the striatum. J Neurochem 36, 1515-1520 (1981)

146 Dray A, Davies J, Oakley NR, Tongroach P and Vellucci S: The dorsal and medial raphe projections to the substantia nigra in the rat: Electrophysiological, biochemical and behavioural observations. Brain Res 151, 431-442 (1978)

147 Dray A, Gonye TJ, Oakley NR and Tanner T: Evidence for the existence of a raphe projection to the substantia nigra in rat. Brain Res 113, 45- 57 (1976)

148 Benloucif S and Galloway MP: Facilitation of dopamine re lease in vivo by serotonin agonists: studies with microdialysis. Eur J Pharmacol 200, 1-8 (1991)

149 Yadid G, Pacak K, Kopin IJ and Goldstein DS: Endogenous serotonin stimulates striatal dopamine release in conscious rats. J Phramacol Exp Ther 270, 1158-1165 (1994)

150 Arborelius L, Momikos GG, Hacksell $U$ and Svensson TH: $(R)-8-\mathrm{OH}$-DPAT preferentially increases dopamine release in rat medial prefrontal cortex. Acta Physiol Scand 148, 465-466 (1993)

151 Galloway MP, Suchowski CS, Keegan MJ and Hjorth S: Local 
infusion of the selective 5HT-1b agonist CP-93,129 facilitates striatal dopamine release in vivo. Synapse 15, 90-92 (1993)

152 Chen J, van Praag HM and Gardner EL: Activation of 5-HT receptor by 1-phenylbiguanide increases dopamine release in the rat nucleus accumbens. Brain Res 543, 354-357 (1991)

153 Bonhomme N, De Deurwaérdere P, Le Moal M and Spampinato $\mathrm{U}$ : Evidence for 5- $\mathrm{HT}_{4}$ receptor subtype involvement in the enhancement of striatal dopamine release induced by serotonin: a microdialysis study in the halothane-anesthetized rat. Neuropharmacology 34, 269-279 (1995)

154 Steward LJ and Barnes NM: The 5- $\mathrm{HT}_{4}$ receptor agonists renzapride and $(S)$-zacopride stimulate dopamine release from rat striatal slices. Br J Pharmacol 111, 155P (1994)

155 Dewey SL, Smith GS, Logan J, Alexoff D, Ding Y-S, King P, Pappas N, Brodie JD and Ashby CR Jr: Serotonergic modulation of striatal dopamine measured with positron emission tomography (PET) and in vivo microdialysis. J Neurosci 15, $821-829$ (1995)

156 Parsons LH and Justice JB Jr: Perfusate serotonin increases extracellular dopamine in the nucleus accumbens as measured by in vivo microdialysis. Brain Res 606, 195-199 (1993)

157 Benloucif S, Keegan MJ and Galloway MP: Serotonin-facilitated dopamine release in vivo: pharmacological characterization. J Phramacol Exp Ther 265, 373-377 (1993)

158 Barnes JM, Barnes NM, Costall B, Naylor RJ and Tyers MB: $5-\mathrm{HT}_{3}$ receptors mediated inhibition of acetylcholine release in cortical tissue. Nature 338, 762-763 (1989)

159 Samanin D, Quattrone A, Peri G, Ladinsky $H$ and Consolo S: Evidence of an interaction between serotoninergic and cholinergic neurons in the corpus striatum and hippocampus of the rat brain. Brain Res 151, 73-82 (1978)

160 Rada PV, Mark GP and Hoebel BG: In vivo modulation of acetylcholine in the nucleus accumbens of freely moving rats: I. inhibition by serotonin. Brain Res 619, 98 - 104 (1993)

161 Sleight AJ, Smith RJ, Marsden CA and Palfreyman MG: The effects of chronic treatment with amitriptyline and MDL 72394 on the control of 5-HT release in vivo. Neuropharmacology 28 , $477-480(1989)$

162 Izumi J, Washizuka M, Miura N, Hiraga Y and Ikeda Y: Hippocampal serotonin $5-\mathrm{HT}_{1 \mathrm{~A}}$ receptor enhances acetylcholine release in conscious rats. J Neurochem 62, 1804- 1809 (1994)

163 Maura $G$ and Raiteri M: Cholinergic terminals in rat hippocampus possess $5-\mathrm{HT}_{1 \mathrm{~B}}$ receptors mediating inhibition of acetylcholine release. Eur J Pharmacol 129, 333-337 (1986)

164 Maura G, Fedele E and Raiteri M: Acetylcholine release from rat hippocampal slices is modulated by 5-hydroxytryptamine. Eur J Pharmacol 165, 173-179 (1989)

165 Nilsson OG, Leanza G and Björklund A: Acetylcholine release in the hippocampus: regulation by monoaminergic afferents as assessed by in vivo microdialysis. Brain Res 584, 132-140 (1992)

166 Consolo S, Bertorelli R, Russi G, Zambelli M and Ladinsky H: Serotonergic facilitation of acetylcholine release in vivo from rat dorsal hippocampus via serotonin 5-HT 3 receptors. J Neurochem 62, 2254-2262 (1994)

167 Bianchi C, Siniscalchi A and Beani L: $5-\mathrm{HT}_{1 \mathrm{~A}}$ agonists increase and $5-\mathrm{HT}_{3}$ agonists decrease acetylcholine efflux from the cerebral cortex of freely-moving guinea pigs. Br J Pharmacol 101, $448-452$ (1990)

168 Maura G, Andrioli GC, Cavazzani P and Raiteri M: 5-Hydroxy-

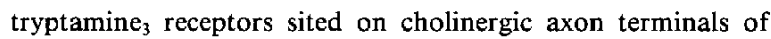
human cerebral cortex mediate inhibition of acetylcholine release. J Neurochem 58, 2334-2337 (1992)

169 Johnson RM, Inouye GT, Eglen RM and Wong EHF: 5-HT receptor ligands lack modulatory influence on acetylcholine release in rat entorhinal cortex. Naunyn Schmiedebergs Arch Pharmacol 347, 241-247 (1993)

170 Ashby CR Jr, Minabe Y, Edwards E and Wang RY: 5-HT -like $^{-}$ receptors in the rat medial prefrontal cortex: and electrophysiological study. Brain Res 550, 181 - 191 (1991)

171 Consolo S, Arnaboldi S, Giorgi S, Russi G and Ladinsky H: $5-\mathrm{HT}_{4}$ receptor stimulation facilitates acetylcholine release in rat frontal cortex. Neuroreport 5, 1230- 1232 (1994)

172 Quirion R, Richard J and Dam TV: Evidence for the existence of serotonin type- 2 receptors on cholinergic terminals in rat cortex. Brain Res 333, 345-349 (1985)

173 Ohue T, Koshimura K, Akiyama Y, Ito A, Kido T, Takagi Y and Miwa S: Regulation of acetylcholine release in vivo from rat hippocampus by monoamines as revealed by novel columnswitching HPLC with electrochemical detection. Brain Res 572, 340-344 (1992)

174 Rutter JJ, Gundlah C and Auerbach SB: Increase in extracelluar serotonin produced by uptake inhibitors is enhanced after chronic treatment with fluoxetine. Neurosci Lett 171, 183-186 (1994)

175 Chaput $\mathrm{Y}$, de Montigny $\mathrm{C}$ and Blier P: Effects of a selective 5HT reuptake blocker, citalopram, on the sensitivity of 5-HT autoreceptors: Electrophysiological studies in the rat brain. Naunyn Schmiedebergs Arch Pharmacol 333, 342-348 (1986)

176 Jolas T, Haj-Dahmane S, Kidd EJ, Langlois X, Lanfumey L, Fattaccini CM, Vantalon V, Laporte AM, Adrien J, Gozlan H and Hamon $\mathrm{M}$ : Central pre- and postsynaptic $5-\mathrm{HT}_{1 \mathrm{~A}}$ receptors in rats treated chronically with a novel antidepressant, cericlamine. J Pharmacol Exp Ther 268, 1432-1443 (1994)

177 Blier $P$ and de Montigny $C$ : Modification of 5-HT neuron properties by sustained administration of the $5-\mathrm{HT}_{1 \mathrm{~A}}$ agonist gepirone: Electrophysiological studies in the rat brain. Synapse 1, 470-480 (1987)

178 Godbout R, Chaput Y, Blier P and de Montigny C: Tandospirone and its metabolite, 1-(2-pyrimidinyl)-piperazine-I. Effects of acute and long-term administration of tandospirone on serotonin transmission. Neuropharmacology 30, 679-690 (1991)

179 Kreiss DS and Lucki I: Desensitization of 5-HT ${ }_{1 \mathrm{~A}}$ autoreceptors by chronic administration of 8-OH-DPAT. Neuropharmacology 31, 1073-1076 (1992)

180 Sharp T, McQuade R, Bramwell S and Hjorth S: Effect of acute and repeated administration of 5- $\mathrm{HT}_{1 \mathrm{~A}}$ receptor agonists on 5HT release in rat brain in vivo. Naunyn Schmiedebergs Arch Pharmacol 348, 339-346 (1993)

181 Söderpalm B, Lundin B and Hjorth: Sustained 5-hydroxytryptamine release-inhibitory and anxiolytic-like action of the partial $5-\mathrm{HT}_{1 \mathrm{~A}}$ receptor agonist, buspirone, after prolonged chronic administration. Eur J Pharmacol 239, 69-73 (1993)

182 Hrdina PD, Foy B, Hepner A and Summers J: Antidepressant binding sites in brain: autoradiographic comparison of $\left[{ }^{3} \mathrm{H}\right]$ paroxetine and $\left[{ }^{3} \mathrm{H}\right]$ imipramine localization and relationship to the serotonin transporter. J Pharmacol Exp Ther 252, 410-418 (1990)

183 Adell A and Artigas F: Differential effects of clomipramine 
given locally or systemically on extracelluar 5-hydroxytryptamine in raphe nuclei and frontal cortex. Naunyn Schmiedebergs Arch Pharmacol 343, 237-244 (1991)

184 Bel N and Artigas F: Fluvoxamine preferentially increases extracellular 5-hydroxytryptamine in the raphe nuclei: an in vivo microdialysis study. Eur J Pharmacol 229, 101-103 (1992)

185 Invernizzi R, Belli S and Samanin R: Citalopram's ability to increase the extracellular concentrations of serotonin in the dorsal raphe prevents the drug's effect in the frontal cortex. Brain Res 584, 322-324 (1992)

186 Hjorth S: Serotonin 5-HT $1 \mathrm{~A}$ autoreceptor blockade potentiates the ability of the 5-HT reuptake inhibitor citalopram to increase nerve terminal output of 5-HT in vivo: A microdialysis study. J Neurochem 60, 776-779 (1993)

187 Artigas F, Perez V and Alvarez E: Pindolol induces a rapid improvement of depressed patients treated with serotonin reuptake inhibitors. Arch Gen Psychiatry 51, 248-251 (1994)

188 Lesch KP, Poten B, Söhnle K and Schulte HM: Pharmacology of hypothermic response to $5-\mathrm{HT}_{1 \mathrm{~A}}$ receptor activation in humans. Eur J Clin Pharmacol 39, 17-19 (1990)

189 Celada $\mathbf{P}$ and Artigas F: Monoamine oxidase inhibitors increase preferentially extracellular 5-hydroxytryptamine in the midbrain raphe nuclei. A brain microdialysis study in the awake rat. Naunyn Schmiedebergs Arch Pharmacol 347, 583-590 (1993)

190 Blier P, Chaput Y and De Montigny C: Long-term 5-HT reuptake blockade, but not monoamine oxidase inhibition, decreases the function of terminal 5-HT autoreceptors: an electrophysiological study in the rat brain. Naunyn Schmiedebergs Arch Pharmacol 337, 246-254 (1988)

191 Blier P and Bouchard C: Modulation of 5-HT release in the guinea pig brain following long-term administration of antidepressant drugs. Br J Pharmacol 113, 485 - 495 (1994)

192 Bolanos-Jiménez F, De Castro RM and Fillion G: Effect of chronic antidepressant treatment on $5-\mathrm{HT}_{1 \mathrm{~B}}$ presynaptic heteroreceptors inhibiting acetylcholine release. Neuropharmacology 33, 77-81 (1994)

193 Sleight AJ, Smith RJ, Marsden CA and Palfreyman MG: The effects of chronic treatment with amitriptyline and MDLL 72394 on the control of 5-HT release in vivo. Neuropharmacology 28, $477-480$ (1989)

194 Mennini T, Mocaer E and Garattini S: Tianeptine, a selective enhancer of serotonin uptake in rat brain. Naunyn Schmiedebergs Arch Pharmacol 336, 478-482 (1987)

195 Montero D, Felipe MC and Del Rio J: Acute or chronic antidepressants do not modify $\left[{ }^{125} \mathrm{I}\right]$ cyanopindolol binding to 5 $\mathrm{HT}_{\mathrm{IB}}$ receptors in rat brain. Eur J Pharmacol 196, 327-329 (1991)

196 Galzin AM, Moret C, Verzier B and Langer S: Interaction between tricyclic and non tricyclic 5-HT uptake inhibitors and the presynaptic 5-HT inhibitory autoreceptors in the rat hypothalamus. J Pharmacol Exp Ther 235, 200-211 (1985)

197 Moret C and Briley M: Sensitivity of the response of 5-HT autoreceptors to drugs modifying synaptic availability of 5-HT. Neuropharmacology 27, 43-49 (1988)

198 Mongeau R, De Montigny C and Blier P: Electrophysiological evidence for the desensitization of $\alpha_{2}$-adrenoceptors on serotonin terminals following long-term treatment with drugs increasing norepinephrine synaptic concentration. Neuropsychopharmacology 10, $41-51$ (1994)
199 Taylor MA: Idazoxan: A selective $\alpha_{2}$-antagonist and effective sustained antidepressant in two bipolar depressed patients. Arch Gen Psychiatry 46, 958 -959 (1989)

200 Mongeau R, De Montigny C and Blier P: Effects of long-term alpha-2 adrenergic antagonists and electroconvulsive treatments on the alpha-2 adrenoceptors modulating serotonin neurotransmission. J Pharmacol Exp Ther 269, $1152-1159$ (1994)

201 Yoshioka M, Matsumoto M, Numazawa R, Togashi H, Smith $\mathrm{CB}$ and Saito $\mathrm{H}$ : Changes in the regulation of 5-hydroxytryptamine release by $\alpha_{2}$-adrenoceptors in the rat hippocampus after long-term desipramine treatment. Eur J Pharmacol 294, $565-570$ (1995)

202 Kahn RS and Davidson M: Serotonin, dopamine and their interactions in schizophrenia. Psychopharmacology (Berlin) 112, S1 - S4 (1993)

203 Arora $\mathrm{R}$ and Meltzer $\mathrm{H}$ : serotonin (5-HT-2) receptor binding in the frontal cortex of schizophrenic patients. J Neural Transm 85, 19-29 (1991)

204 Kane J, Honigfeld G, Singer J and Meltzer H: Clozapine for the treatment resistant schizophrenic: a double blind comparison study with chlorpromazine/bentropine. Arch Gen Psychiatry 45, 789-796 (1988)

205 Kitaichi K, Yamada K, Hasegawa T, Furukawa H and Nabeshima T: Effects of risperidone on phencyclidine-induced behaviors: comparison with haloperidol and ritanserin. Jpn J Pharmacol 66, 181 - 189 (1994)

206 Povlsen UJ, Noring U, Fog R and Gerlach J: Tolerability and therapeutic effect of clozapine. Acta Psychiatry Scand 71, $176-185$ (1985)

207 Gerlach J, Thorsen K and Fog R: Extrapyramidal reactions and amine metabolites in cerebrospinal fluid during haloperidol and clozapine treatment of schizophrenia patients. Psychopharmacology (Berlin) 40, 341-350 (1975)

208 Stone DM, Stahl DC, Hanson GR and Gibb JW: The effects of 3,4-methylenedioxymethamphetamine (MDMA) and 3,4methylenedioxyamphetamine (MDA) on monoaminergic systems in the rat brain. Eur J Pharmacol 128, $41-48$ (1986)

209 Battaglia G, Yeh SY, O'Hearn E, Molliver ME, Kuhar MJ and De Souza EB: 3,4-Methylenedioxymethamphetamine and 3,4methylenedioxyamphetamine destroy serotonin terminals in rat brain: Quantification of neurodegeneration by measurement of $\left[{ }^{3} \mathrm{H}\right]$ paroxetine-labeled serotonin uptake sites. J Pharmacol Exp Ther 242, 911-916 (1987)

210 O'Hearn E, Battaglia G, De Souza EB, Kuhar MJ and Molliver ME: Methylenedioxyamphetamine (MDA) and methylenedioxymethamphetamine (MDMA) cause selective ablation of serotonergic axon terminals in forebrain: immunocytochemical evidence for neurotoxicity. J Neurosci 8, 2788-2803 (1988)

211 Hiramatsu $M$ and Cho AK: Enantiomeric differences in the effects of 3,4-methylenedioxymethamphetamine on extracellular monoamines and metabolites in the striatum of freelymoving rats: an in vivo microdialysis study. Neuropharmacology $29,269-275$ (1990)

212 Nash JF and Nichols DE: Microdialysis studies on 3,4methylenedioxyamphetamine and structurally related analogues. Eur J Pharmacol 200, 53-58 (1991)

213 Nash JF and Brodkin J: Microdialysis studies on 3,4methylenedioxymethamphetamine-induced dopamine release; Effect of dopamine uptake inhibitors. J Pharmacol Exp Ther 259, 820-825 (1991) 
214 Schmidt CJ, Sullivan CK and Fadayel GM: Blockade of striatal 5 -hydroxytryptamine $e_{2}$ receptors reduces the increase in extracellular concentrations of dopamine produced by the amphetamine analogue 3,4-methylenedioxymethamphetamine. J Neurochem 62, 1382-1389 (1994)

215 Yamamoto BK, Nash JF and Gudelsky GA: Modulation of methylenedioxymethamphetamine-induced striatal dopamine release by the interaction between serotonin and $\gamma$-aminobutyric acid in the substantia nigra. J Pharmacol Exp Ther 273, 1063-1070 (1995)

216 Gudelsky GA, Yamamoto BK and Nash JF: Potentiation of 3,4-methylenedioxymethamphetamine-induced dopamine release and serotonin neurotoxicity by $5-\mathrm{HT}_{2}$ receptor agonists. Eur J Pharmacol 264, 325-330 (1994)

217 Yamamoto BK and Meltzer HY: The effect of the atypical antipsychotic drug, amperozide, on carrier-mediated striatal dopamine release measured in vivo. J Pharmacol Exp Ther 263, 180-185 (1992)
218 Ichikawa J and Meltzer HY: Amperozide, a novel antipsychotic drug, inhibits the ability of $d$-amphetamine to increase dopamine release in vivo in rat striatum and nucleus accumbens. $\mathbf{J}$ Neurochem 58, 2285-2291 (1992)

219 Svensson TH, Mathé JL, Andersson JL, Nomikos GG, Hildebrand $\mathrm{BE}$ and Marcus M: Mode of action of atypical neuroleptics in relation to the phencyclidine model of schizophrenia: role of 5- $\mathrm{HT}_{2}$ receptor and $\alpha_{1}$-adrenoceptor antagonism. J Clin Psychopharmacol 15, 11S-18S (1995)

220 Moghaddam B and Bunney BS: Acute effects of typical and atypical antipsychotic drugs on the release of dopamine from prefrontal cortex, nucleus accumbens, and striatum of the rat: an in vivo microdialysis study. J Neurochem 54, 1755-1760 (1990)

221 Wiesel F-A, Nordstrm A-L, Farde L and Eriksson B: An open clinical and biochemical study of ritanserin in acute patients with schizophrenia. Psychoparmacology (Berlin) 114, 31-38 (1994) 